\title{
Annual Fluctuations and Displacements of Inter Tropical Convergence Zone (ITCZ) within the Range of Atlantic Ocean-India
}

\author{
Hassan Lashkari*, Zainab Mohammadi, Ghassem Keikhosravi \\ Department of Synoptic Climatology, Shahid Beheshti University, Tehran, Iran \\ Email: ${ }^{*}$ r_lashkari61@yahoo.com
}

How to cite this paper: Lashkari, H., Mohammadi, Z. and Keikhosravi, G. (2017) Annual Fluctuations and Displacements of Inter Tropical Convergence Zone (ITCZ) within the Range of Atlantic Ocean-India. Open Journal of Ecology, 7, 12-33. http://dx.doi.org/10.4236/oje.2017.71002

Received: June 20, 2016

Accepted: January 15, 2017

Published: January 18, 2017

Copyright $\odot 2017$ by authors and Scientific Research Publishing Inc. This work is licensed under the Creative Commons Attribution International License (CC BY 4.0).

http://creativecommons.org/licenses/by/4.0/ c) (i) Open Access

\begin{abstract}
Inter Tropical Convergence Zone (ITCZ) is one of the major systems in making the general circulation of atmosphere. Many climatologists believe that the starting point of the general circulation of atmosphere is from this system. It seems that the annual displacement of this system is coordinated with the sun. In this study we have tried to investigate the annual and seasonal displacement of this system within the range of Middle East, especially within the range of longitude of Iran in a long period of time (statistical period of 66 years). This is the first study in the field of ITCZ monthly and annual longterm changes in Iran. In this study, not only his exact position on Africa and South West Asia ITCZ is determined, it also shows the change in the period of 66 years. These results can also be used on regional climate changes. For this purpose topographic and surface level pressure maps are 1000 and $850 \mathrm{hpa}$ and they were approximately extracted monthly for 12 months of the year from 1948 to 2013 and also they were extracted from the National Oceanic and Atmospheric Administration Site in America within the range of $30^{\circ}$ west to $110^{\circ}$ east, and they were extracted by using the flow map of location (ITCZ). Due to the sudden displacement in the ITCZ bar path in the two seasons of summer and winter, on the Middle East region, the direct impact of this displacement on sudden changes of seasons, the start and end of untimely rains, its impacts on agricultural products and water recourses of the country so all these reasons are essential that this phenomenon should be studied carefully. Studies have shown that ITCZ is not a coordinated solar system and its displacement is not coordinate with the apparent annual displacement of the sun. October is the only month of ITCZ that within the range of 10 northern degrees in all the ranges of longitude $20^{\circ}$ west to $110^{\circ}$ east has an approximate orbital shape. In 6 months of the year (from November to April) (ITCZ) within the range of $30^{\circ}$ east or $110^{\circ}$ east, it is entirely located in the Southern Hemisphere and on the contrary in 5 months from May to September (ITCZ) within the range of $30^{\circ}$
\end{abstract}


east to $110^{\circ}$ east, it is entirely located in the Northern Hemisphere. And in this period, ITCZ has its highest Northern movement on the Earth. So that at the foot of the Himalayas it moves to $30^{\circ}$ north. Within the range of Africa, ITCZ never enters the Southern Hemisphere at any time of the year. And the interesting phenomenon of severe refraction in the way of ITCZ, during the cold period, is within the range of Ethiopia and ITCZ has approximately redirected for Meridian and enters the Southern Hemisphere.

\section{Keywords}

ITCZ, Atlantic Ocean-India, Annual Fluctuations, Displacements

\section{Introduction}

Inter Tropical Convergence Zone (ITCZ) is one of the constructive elements of general circulation of the atmosphere. In other words, the starting point of general circulation of atmosphere is from this system. This system complies with the monthly and seasonal changes of the sun, moves to the northern and southern latitudes and consequently affects the general circulation of the atmosphere. For example in late spring and all summer, the Northern hemisphere, with increasing intensity of solar radiation in the Northern margin of equator, Inter Tropical Convergence Zone (ITCZ) moves to more Northern latitudes [1]. This system, like all other systems, has unique features that cannot be seen in other systems. Phil Andrew et al. have studied the reason for deployment of Tropical Convergence Zone belt in the North of equator and have concluded that the asymmetric distribution of land and water area, geometry of the Earth and receiving unequal sun light and temperature difference between sea levels cause the asymmetry of ITCZ [2]. Eliezer and Gautier, relying on satellite climatology, have determined the intensity of convergence and orbital changes of Tropical Convergence Belt [3]. Zhang by applying spectral analysis models and wavelet analysis has investigated the ITCZ disorders in Synoptic scale and has expressed that these models have observed the annual, monthly and periodic changes in Tropical Convergence Belt [4]. Arbuszewski et al. in a research entitled "Studying the Effect of Tropical Convergence Zone on Aerosols" have shown that air masses of dust are fully associated with the location of ITCZ [5]. Seasonal variation in the spatial distribution of aerosols over Africa and nearby oceans is related to the large-scale atmospheric circulation, which is manifested by seasonal changes in the position of the intertropical convergence zone [6] and subsequent variations in the location and intensity of circulation centers [7] [8] [9]. The ITCZ is characterized by the convergence of dry northeasterly trade winds blowing over the Sahara, the so-called Harmattan winds, and humid south easterly winds originating farther south over the tropical Atlantic Ocean [7]. Farther south in the Sahel and southern fringes of the Sahara, the rainy season associated with north ward movement of the ITCZ and invasion of southerly warm and moist air from 
tropical regions results in reduced dust activity in summer. Over the Sahelian region, however, the summertime southerly warm and moist air is replaced by the wintertime northerly dry continental flows, which tend to generate dust storms in desert areas [10]. The extent of African dust over the Atlantic Ocean and its latitudinal variation with season is also related to changes in wind patterns over the region. During winter, the easterly low level jet [11], over the tropical Atlantic Ocean, contribute to longer distance transport of African dust during summer. Note that the Azores-Bermuda high-pressure circulation also transports aerosol-laden air from the tropical North Atlantic into subtropical regions [12] [13]. Zhang proceeded to navigate the Tropical Convergence Belt using the tracking of deep convective clouds, and they have concluded that is a proper method for determining the location of ITCZ [4]. Rajendran et al. by using a simulation model of water-planet have studied the effects of changes of sea surface temperatures over the Tropical Convergence Belt. They have concluded that internal comparison of the model shows that the occurrence and position of ITCZ is primarily related to the boundary layer of moisture convergence, in response to the Meridian diversity of changes in the sea surface temperature (SST). And moreover, the Meriden gradient of tropospheric temperature is an important factor that can affect the position of ITCZ [14]. Most annual shift Inter tropical convergence zone between the Sahara Desert and the South East Asia region occur. This shift heavily on Iran and the region affects climate. ITCZ was moving south ward in winter with Saudi Arabia subtropical high pressure, western waves and causing precipitation systems can be entered Iran. In contrast, in the summer with the ITCZ move north ward and the rule of Saudi Arabia subtropical high pressure on Iran rains in most parts of it will be cut off. This shift start and end time determines the precipitation of Iran and the region. In this research it has been tried to investigate the displacements of time and place in Tropical Convergence Zone (ITCZ), in geographical range in the Middle East and Iran during a long statistical period (66 years). Always among Iranian and Iraqi climatologists, this question has been raised that: "Why in some years rains start before the deadline and in some years, autumn rains start earlier than the deadline?" The same question was raised about the end of rains in spring. Also according to the research conducted by authors on the low pressure system of Sudan, this question was raised that: "What is the reason for the formation of a low pressure system on Sudan?" It seemed that these anomalies were related to the unusual displacement in Inter Tropical Convergence Zone (ITCZ). For this reason, in the first research it has been tried to examine the long-held position of ITCZ and in another research to study the climatic anomalies of surrounding countries (early and late start and end of rains, severe seasonal changes, hot and cold waves).

\section{Methodology}

In this research annual fluctuations and displacements of Tropical Convergence Zone within the range of Atlantic Ocean-India in the statistical period (1948-2013) 
have been investigated. Since the minimum local wind speed can represent the location of ITCZ, at first in order to determine the position of the belt, the annual wind speed map has been used by using daily data of ERA-Interim and the cross-section (profile) of mean zonal of wind zonal of average data for geographical range $20^{\circ} \mathrm{W}-110^{\circ} \mathrm{E}$ and $35^{\circ} \mathrm{S}-40^{\circ} \mathrm{N}$ for all months in the period of (1984-2013), in the software environment of GRADS. In annual scale the average location of Tropical Convergence Zone, that zonal winds at ground level reach zero, complies on the equator line. Also to obtain the position of this line, for different periods of time, MATLAB software has been used. And finally outputs of maps have been drawn in GIS software environment.

\section{Results}

\subsection{October}

This month in ecological literature is known as equinox month and in solar calendar is considered as the beginning month of water year in Iran. In other words, the sun is in its second equinox and it is expected that the position of ITCZ, comply with the deployment of the sun to be located within the range of equator. Figure 1 shows an example of the motion path of ITCZ in each month of the statistical period (2005-2013), within the range of latitude $20^{\circ}$ west to $110^{\circ}$ east. It can be seen that within the range of Sudan and Red Sea (ITCZ), there is a northern stretch in all the months of October in decade (2005-2013).

This pattern is seen in all decades and all the years approximately with intensity and weakness.

Figure 1 shows the average position of ITCZ in the period of ten years. It

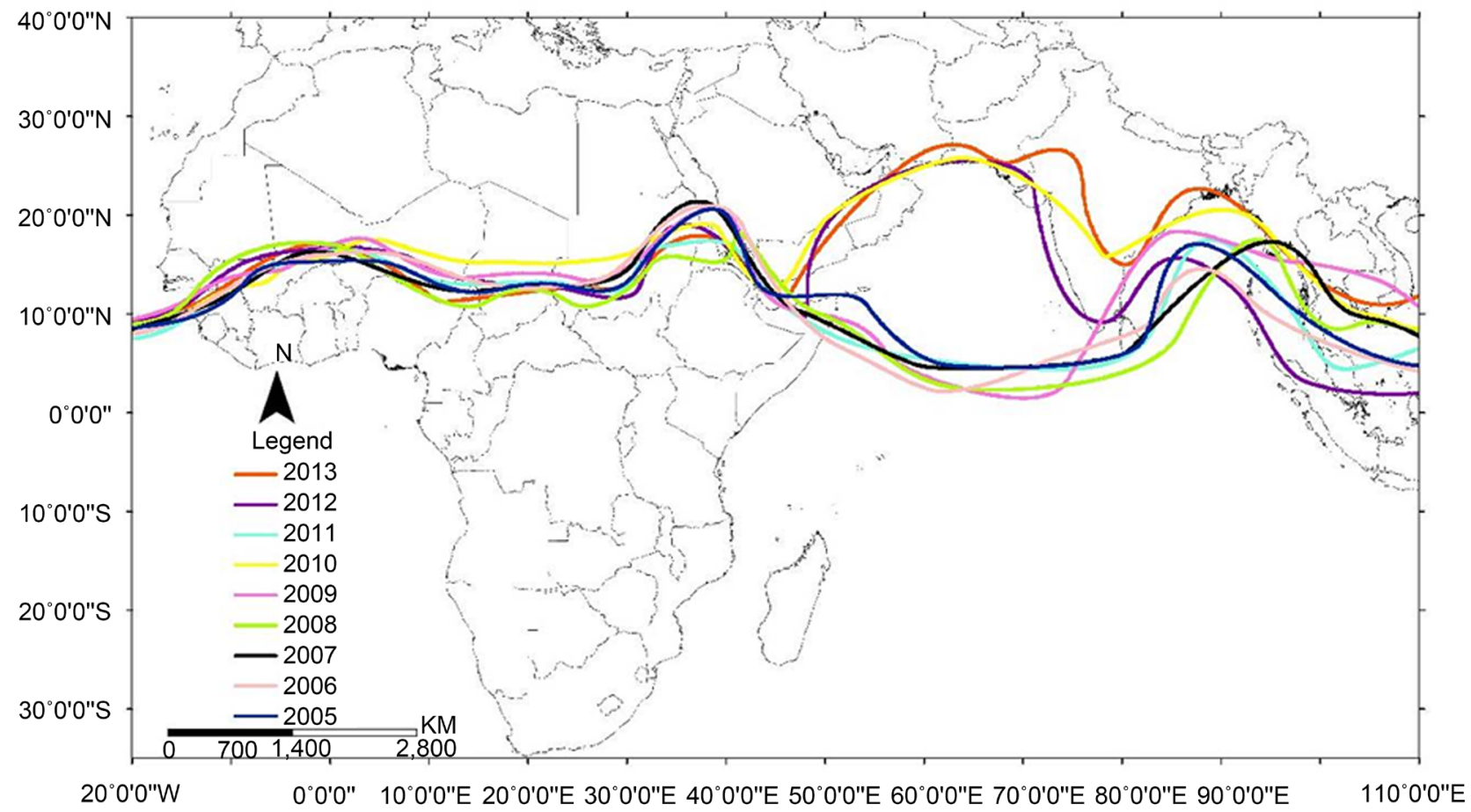

Figure 1. An example of motion path ITCZ in the statistical period (2005-2013). 
also shows this kind of pattern, in all decades in the range of Sudan. There is a southern wave in most of the years, towards East on the Arabian Peninsula, particularly in its eastern half and in few years this concavity cannot be seen. The position of ITCZ on Sea of Oman and Arabian Sea is biaxial. In some years the position of ITCZ, continues to comply with the Northern expansion (ITCZ) and is still in high latitudes and in some years (ITCZ) has withdrew to the lower latitudes. This phenomenon is also seen in all decades. In general, as well as it can be seen on Figure 2, years (1948-1957) have the highest position in the period of (66 years) and decade (1977-1987) has the lowest position (ITCZ) in this month. However it is observed that the position of ITCZ in all months is higher than 10 Northern degrees and is located in the range of 15 to 20 Northern degrees latitude.

\subsection{November}

It is expected that in this month the position of ITCZ moves into lower latitudes. Figure 3 shows the average position of ITCZ in the period of ten years. In this month, ITCZ has taken a more flat mode and does not have the distortion in October. The position of ITCZ up to about $30^{\circ}-35^{\circ}$ east, is still above $10^{\circ}$ east. But it has been dislocated from 35 degrees around the equator and sometimes to 5 Southern degrees. This condition is seen in the motion path of ITCZ in each of the years. For example, Figure 4 shows the location and motion path of ITCZ in each month of November in decade (1980-1987). A conducted survey about the motion path and position of ITCZ has confirmed this condition in other decades. Refraction in the motion path of ITCZ in the range of $30^{\circ}$ to $35^{\circ}$ latitudes

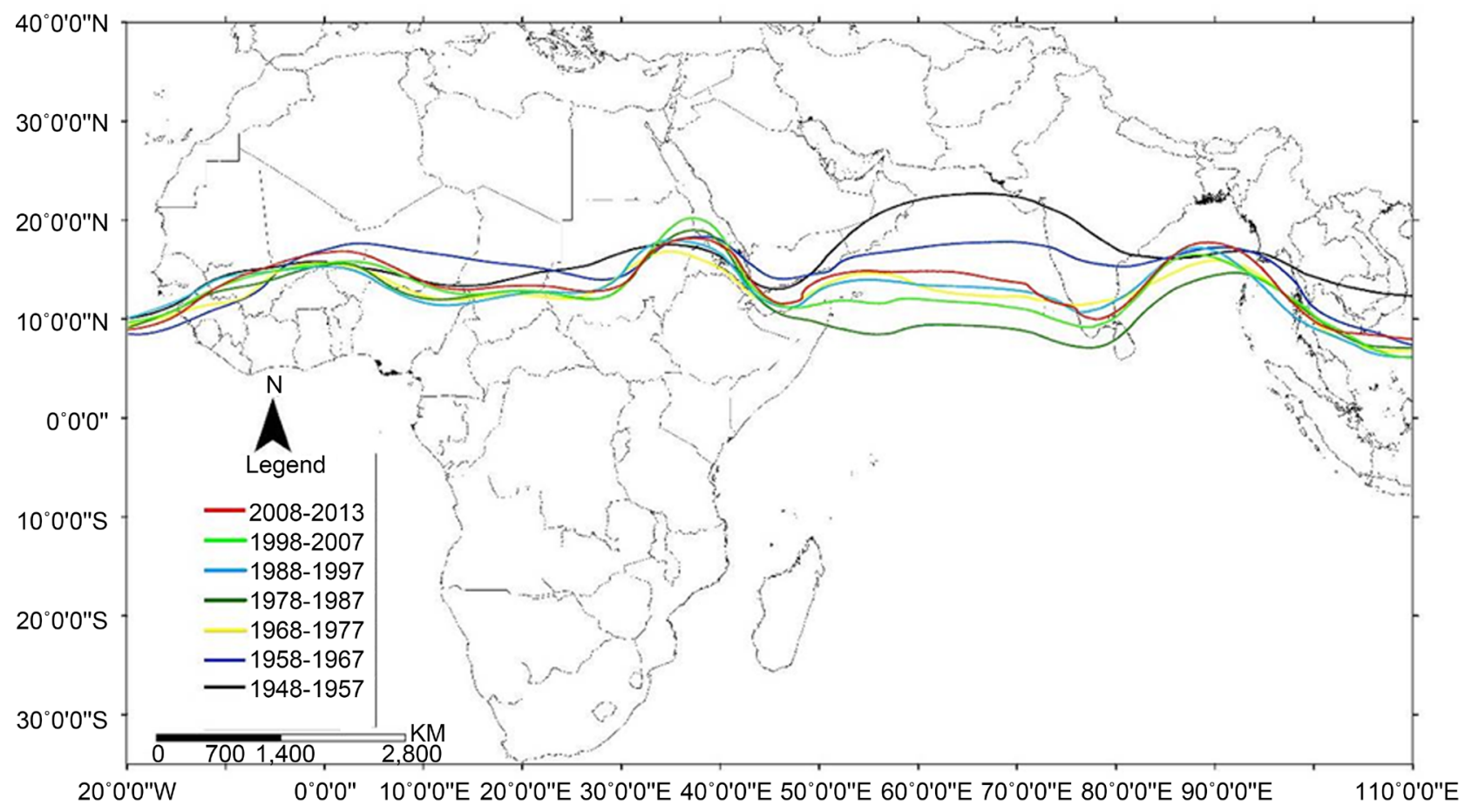

Figure 2. The average position of ITCZ in the period of ten years. 


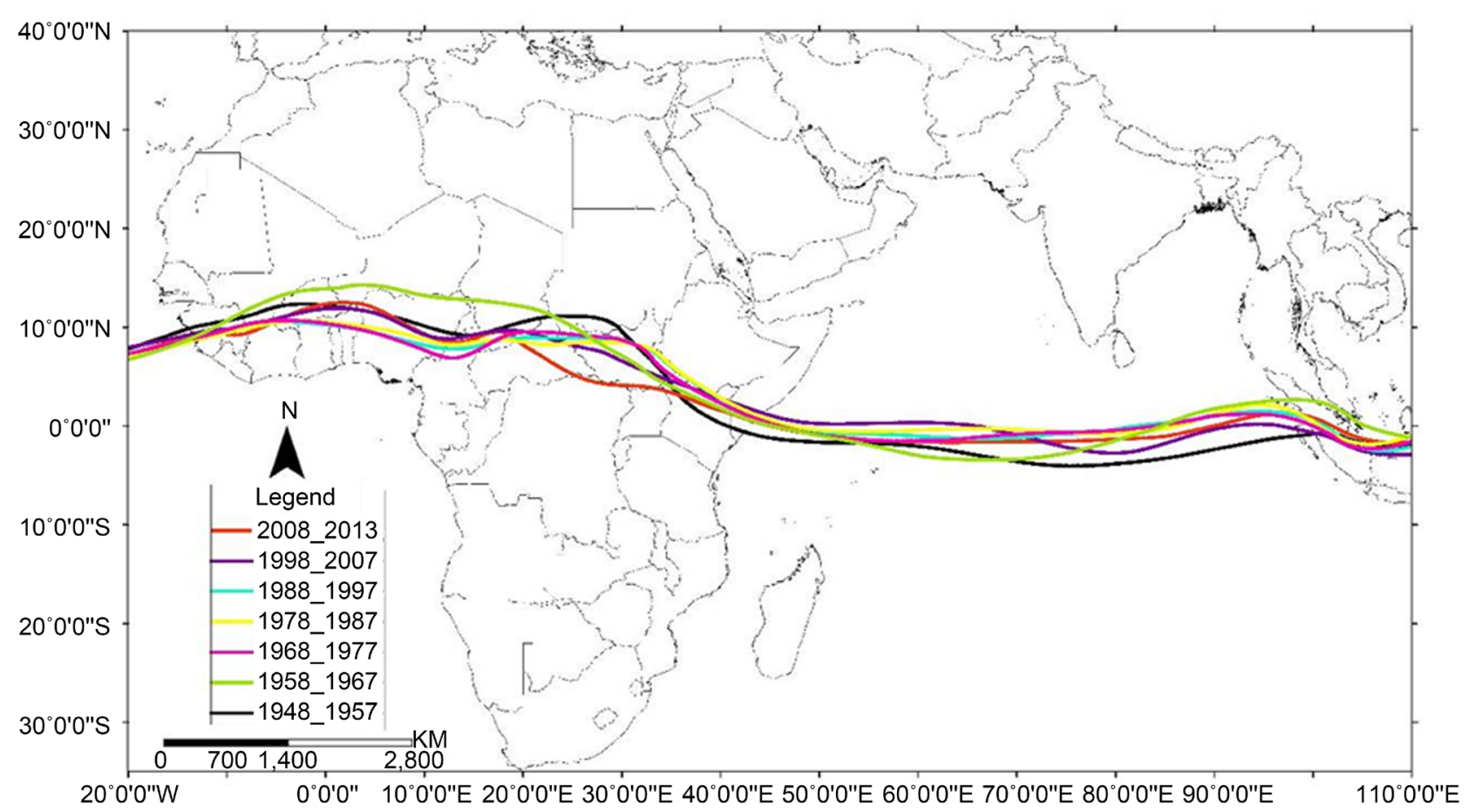

Figure 3. Average position of ITCZ in the period of ten years.

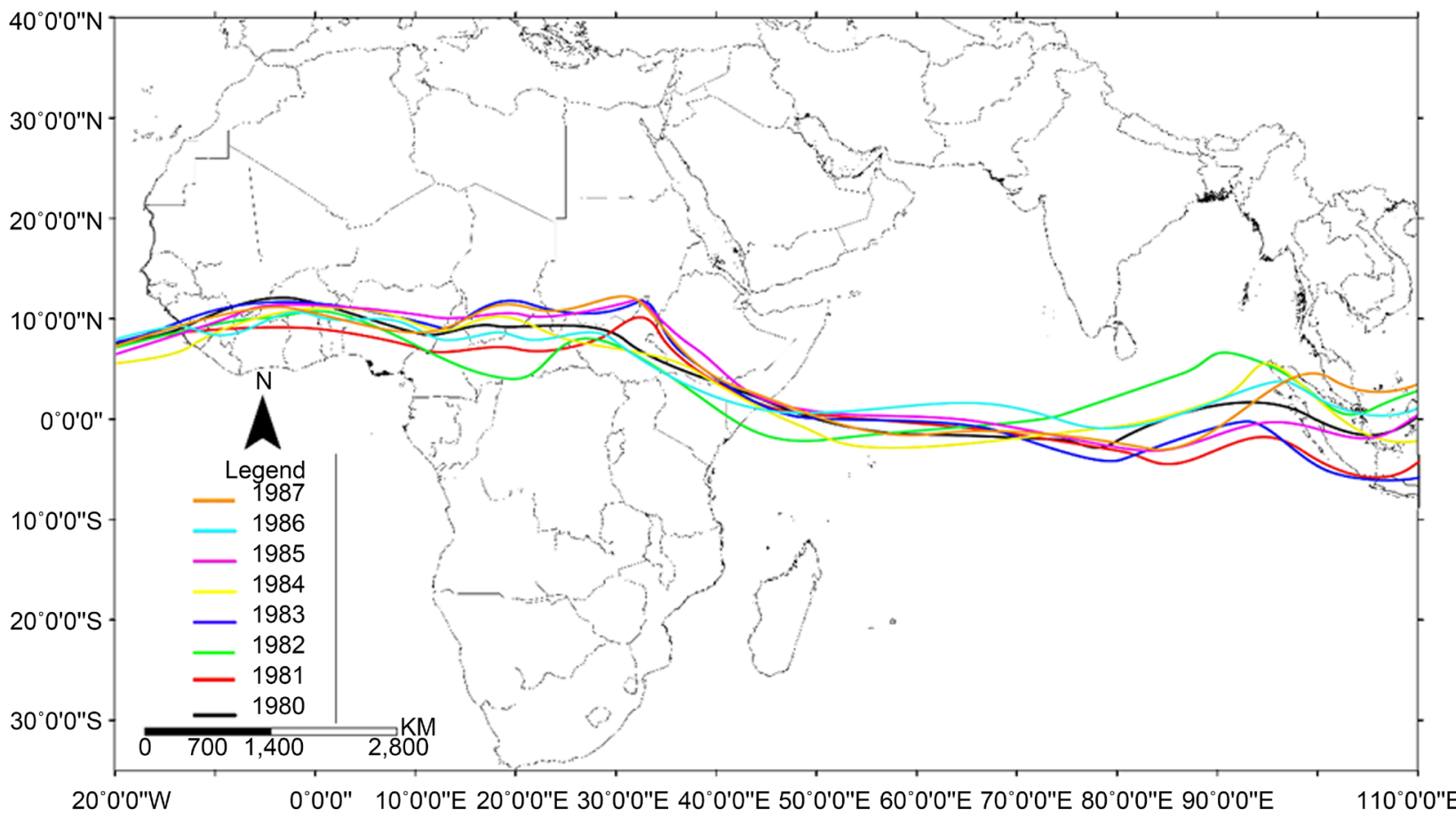

Figure 4. Position and motion path of ITCZ in the statistical period (1980-1987).

(in the position of Southern Sudan and Northern Ethiopia seems to be associated with the Southern pressure move towards Saudi Arabia).

\subsection{December}

Figure 5 shows the position and motion path of ITCZ in each six decades. In 
this month also the motion path of ITCZ in the range of Western $20^{\circ}$ to Eastern $20^{\circ}$ latitudes are higher than the equator and sometimes shows the shift to 10 Northern degrees.

It was expected that in this month because of moving towards South, the direction of general circulation of atmosphere (ITCZ) be located in a position more Southern than the equator. But its motion path is higher than the equator and the motion path of move is suddenly refracted toward Southern latitudes in the range of $20^{\circ}$ east (About 10 degrees more western than November). Then, after passing above the Arabian Sea, on the Ocean it shifts a little towards North and continues its way towards the range of Southern degree. Again this clear and remarkable refraction in the position of ITCZ is because of Southern move toward the high-pressure cell which is in Saudi Arabia. So gradually the expansion of Siberian high pressure tab happens on the Eastern half of Iran, Sea of Oman and Arabian Sea.

In this month the high-pressure Siberian tab is reinforced and generally its Southern tab expands on its Eastern half and Sea of Oman [15]. Figure 6 shows an example of the position of monthly motion path (ITCZ) in the months of decade (2005-2013). It can be seen that the monthly position of motion path ITCZ shows good conformity with its average position in ten years and this phenomenon has been dominant in other years of the other decades.

\subsection{January}

In this month the average condition of move (ITCZ) is very similar to the pattern of December. Also in this month the motion path of ITCZ is located in the

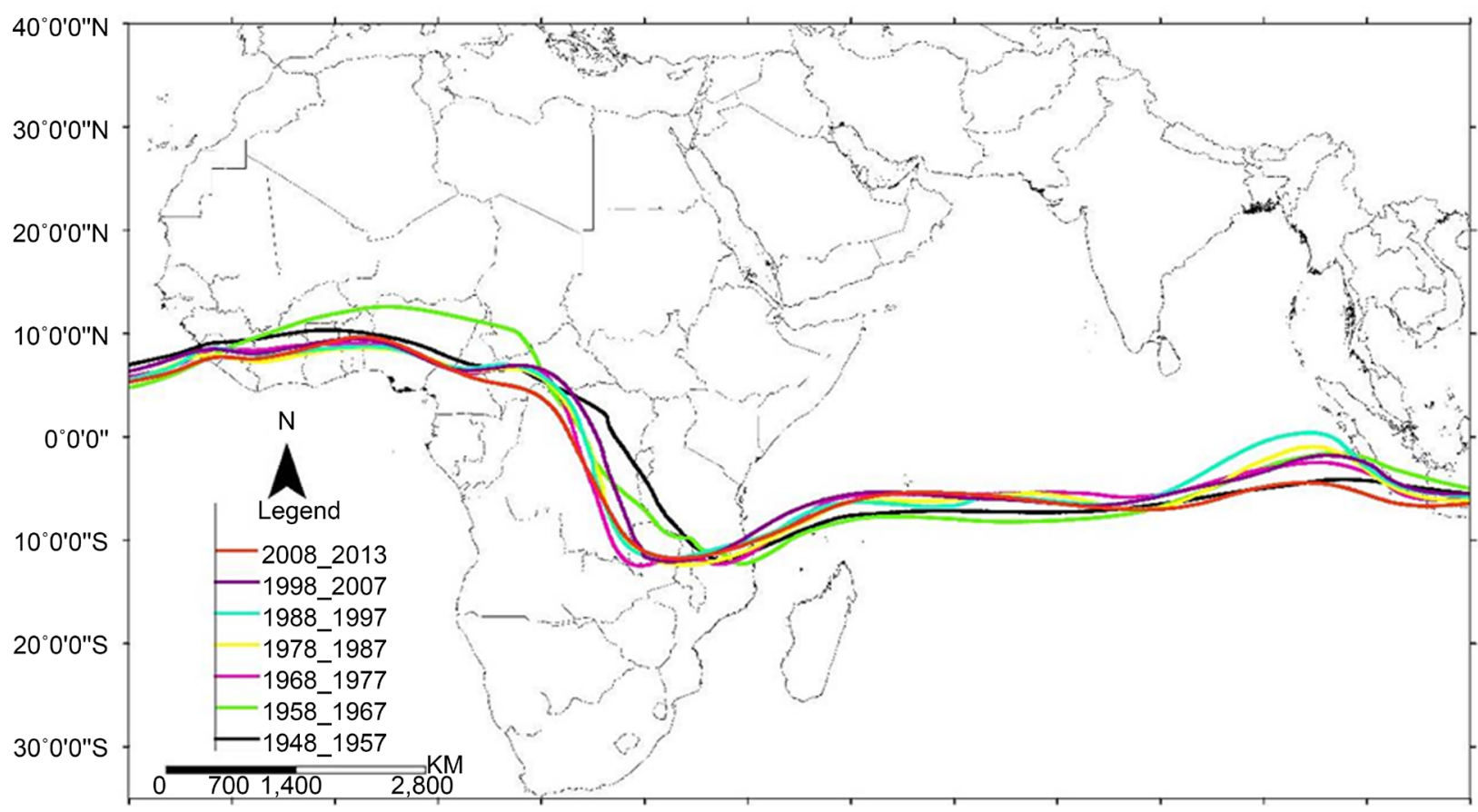

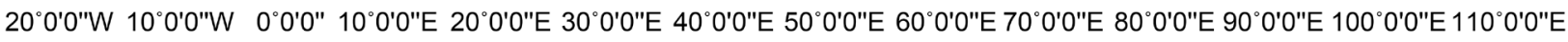

Figure 5. Average position of ITCZ in periods of ten years. 


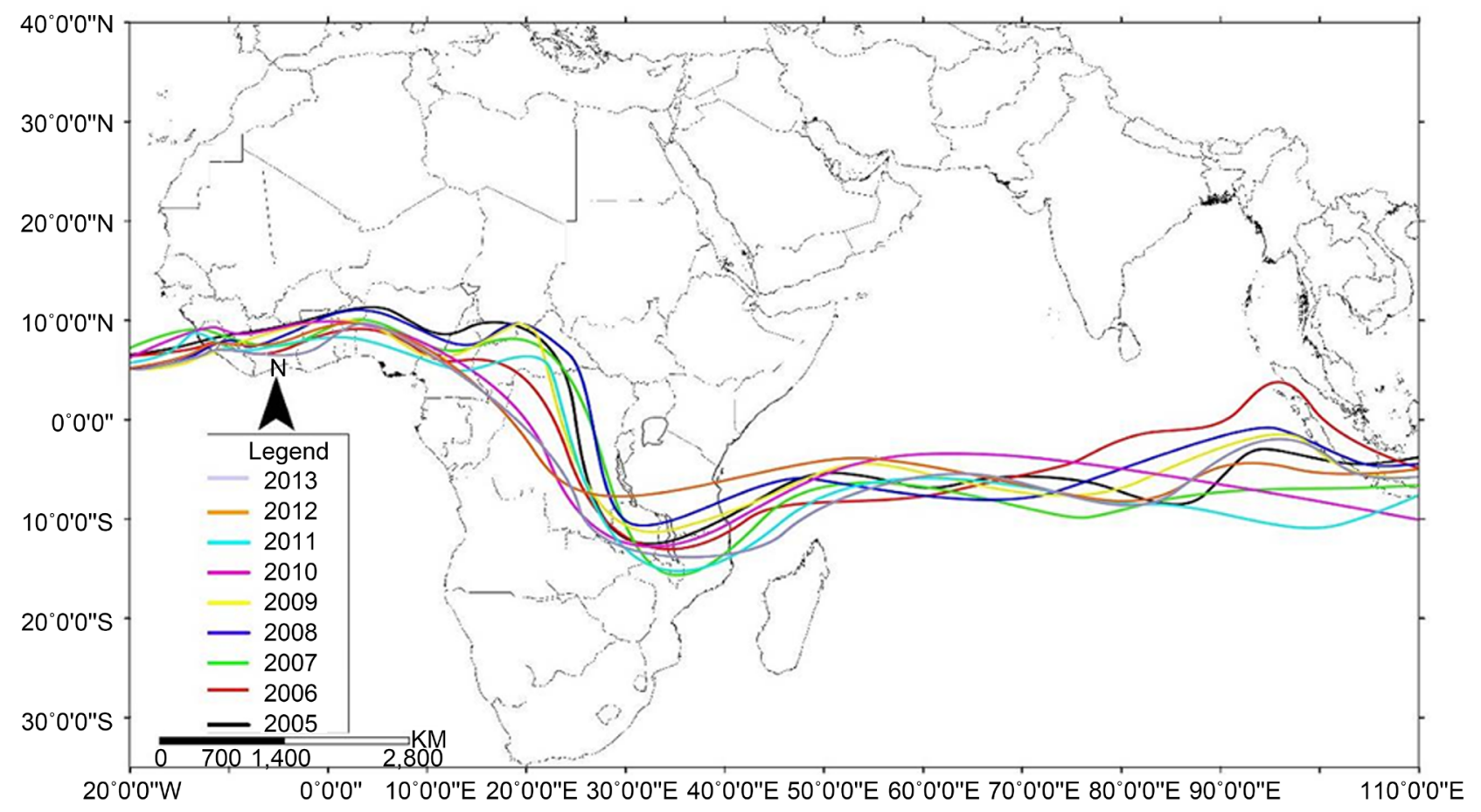

Figure 6. Position and motion path (ITCZ) in the statistical period (2005-2013).

range of $20^{\circ}$ west to $35^{\circ}$ east along the orbits of 5 to 10 northern degrees. And in the range of $35^{\circ}$ latitude, it is suddenly faced with a sudden redirect and a severe refraction. So, ITCZ is perpendicular to the latitude of $5^{\circ}$ north and moves to the latitude of $20^{\circ}$ south. In the following this stretch moves northwards. And along the orbit $5^{\circ}$ south continues toward East. Then with a gradual slope reaches the range of latitude $90^{\circ}$ east to $100^{\circ}$ east to near the equator. Figure 7 shows this phenomenon for decades of ten years. This general mode can be seen in monthly features. Except few examples (66 years) it continues this pattern Figure 8 shows an example of motion path (ITCZ) in each month during years of (2005-2013). It seems that the severe refraction in the motion path (ITCZ) is in the range of latitudes $30^{\circ}$ to $35^{\circ}$ eastern (Ethiopia). Also because of Southern shift toward the high-pressure cell next to tropical Arabia and the influence of Siberian high pressure tab toward lower latitudes above Afghanistan and Eastern half of Iran.

\subsection{February}

Figure 9 shows the motion pattern and motion path (ITCZ) in February during a ten-year period in the statistical period of 66 years. It can be seen that the dominant pattern is similar to the dominant pattern in November, December and January. This pattern does not show remarkable change compared to the previous months. Only there is a minor change in the depth of influence and shift (ITCZ) to the Southern hemisphere and it seems that it is located about 2 to 3 degrees higher than the position in January. Decade (1958-1963) is located in a higher position compared to other decades. In the monthly pattern of this period 
this inconsistency can be seen. Figure 10 shows the motion path of ITCZ in each year of this statistical period.

\subsection{March}

General dominant pattern in this month is very similar to the previous four

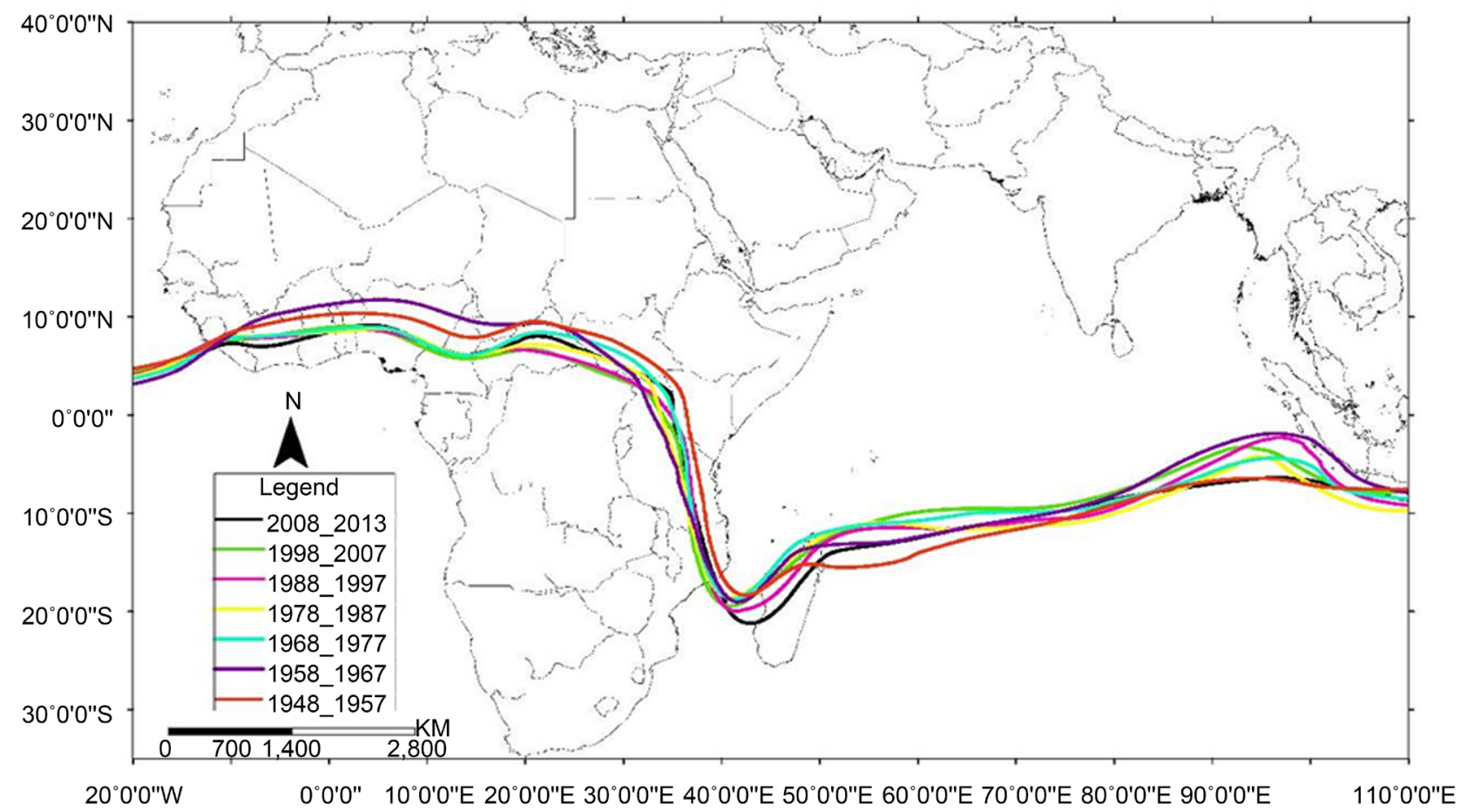

Figure 7. Average position of ITCZ in periods of ten years.

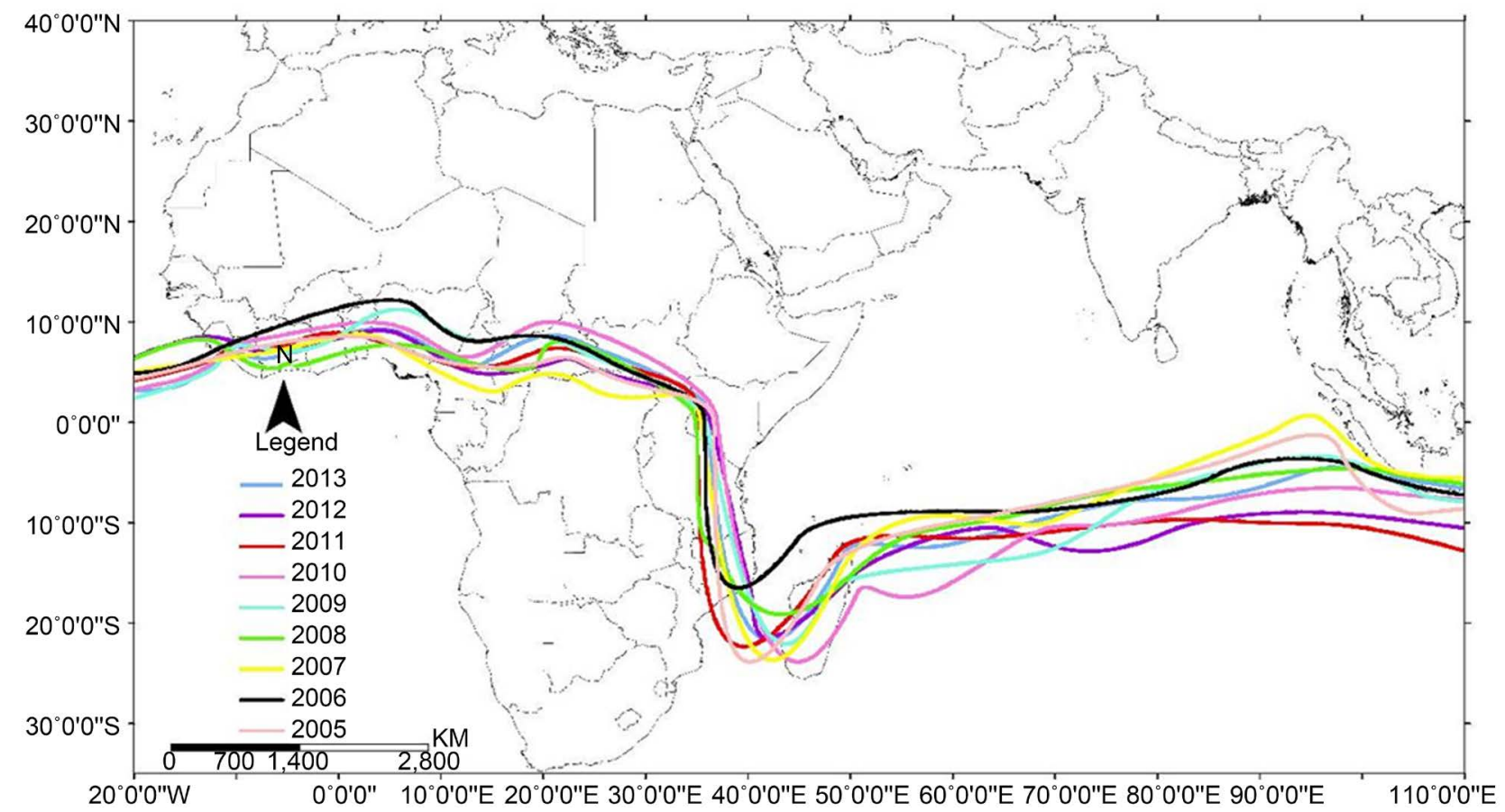

Figure 8. Position and motion path (ITCZ) in the statistical period (2005-2013). 


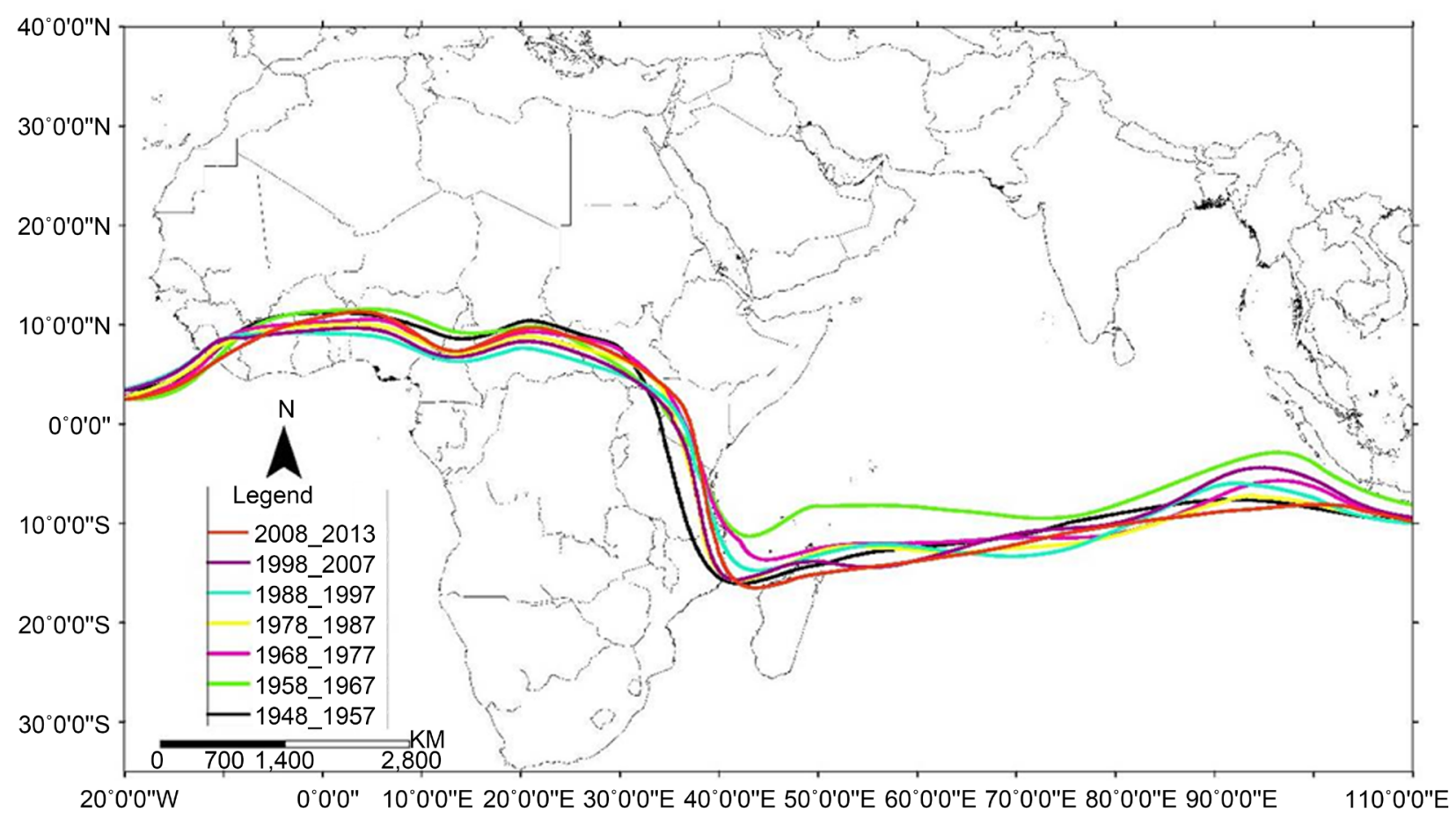

Figure 9. Average position (ITCZ) in periods of ten years.

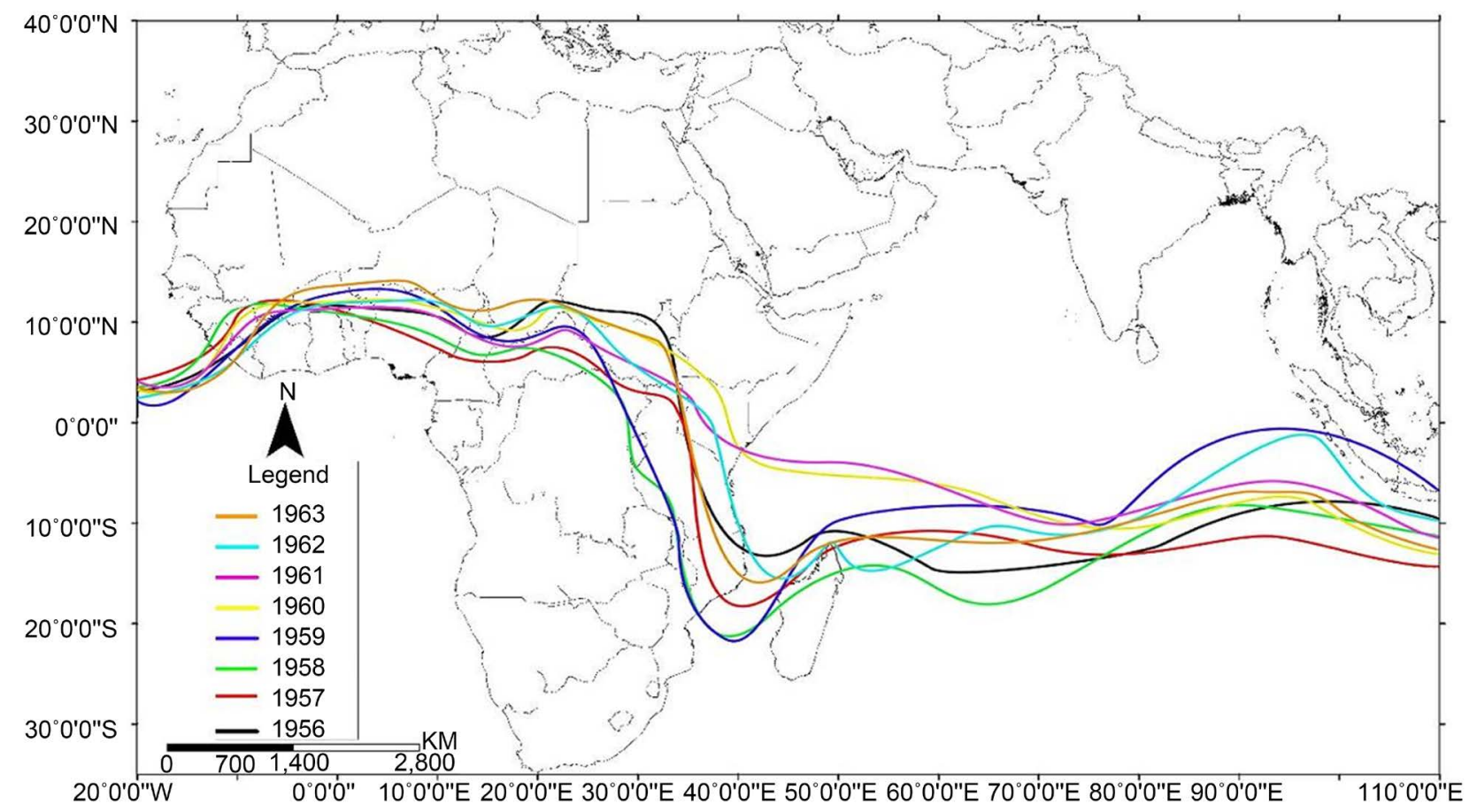

Figure 10. Position and motion path of ITCZ in the statistical period (1956-1963).

months. But a significant difference can be seen in the Northern side displacement in all latitudes. The position of ITCZ in the range of $10^{\circ}$ west to $30^{\circ}$ east has been stretched in the range of $10^{\circ}$ north orbits and from the latitude about $30^{\circ}$ east, has redirected towards South with an almost severe slope. And after passing the motion path of 20 degrees it has reached to the $10^{\circ}$ south orbit. It has 
been stretched from the range of $40^{\circ}$ east latitude in the range of orbits $5^{\circ}$ to $10^{\circ}$ south to $110^{\circ}$ east. Therefore winter pattern can also be seen in this month. Among the ten-year periods of statistical period (1956-1963) the most displacement of Southern-side, has been occurred in the range of latitudes 30 to 40 eastern degrees. In contrast, in the range of latitudes $90^{\circ}$ to $100^{\circ}$ east in the range of Archipelago of Indonesia in all years (ITCZ), there was a significant bulge towards North. Figure 11 and Figure 12 show this phenomenon very well.

\subsection{April}

In climatology this month is considered as month of equinox. It seems that with displacement of the sun towards the equator (ITCZ), it will be located at this range. Figure 13 shows the position and motion path (ITCZ) in the average periods of ten years in this month. The general dominant pattern is very similar to winter pattern (ITCZ). There is a little difference compared to previous months. This difference is the Northern-side displacement in all years. In the range of $10^{\circ}$ to $40^{\circ}$ east (ITCZ) it has been shifted about 5 degrees towards North. The sudden refraction and redirection that has happened in the previous months in the range of latitudes 30 to 35 degrees, and this month has occurred in the range of 40 degrees. The refraction slope compared to previous months has been more flat and in Southern hemisphere has not reached to lower than 5 degrees orbit. In other words, ITCZ within the range of $45^{\circ}$ to $110^{\circ}$ east has stretched on the orbit of 0 to 5 degrees (equator). Certainly the annual changes have been very different in this range. Figure 14 shows the motion path (ITCZ) in each year from 2005 to 2013 in April.

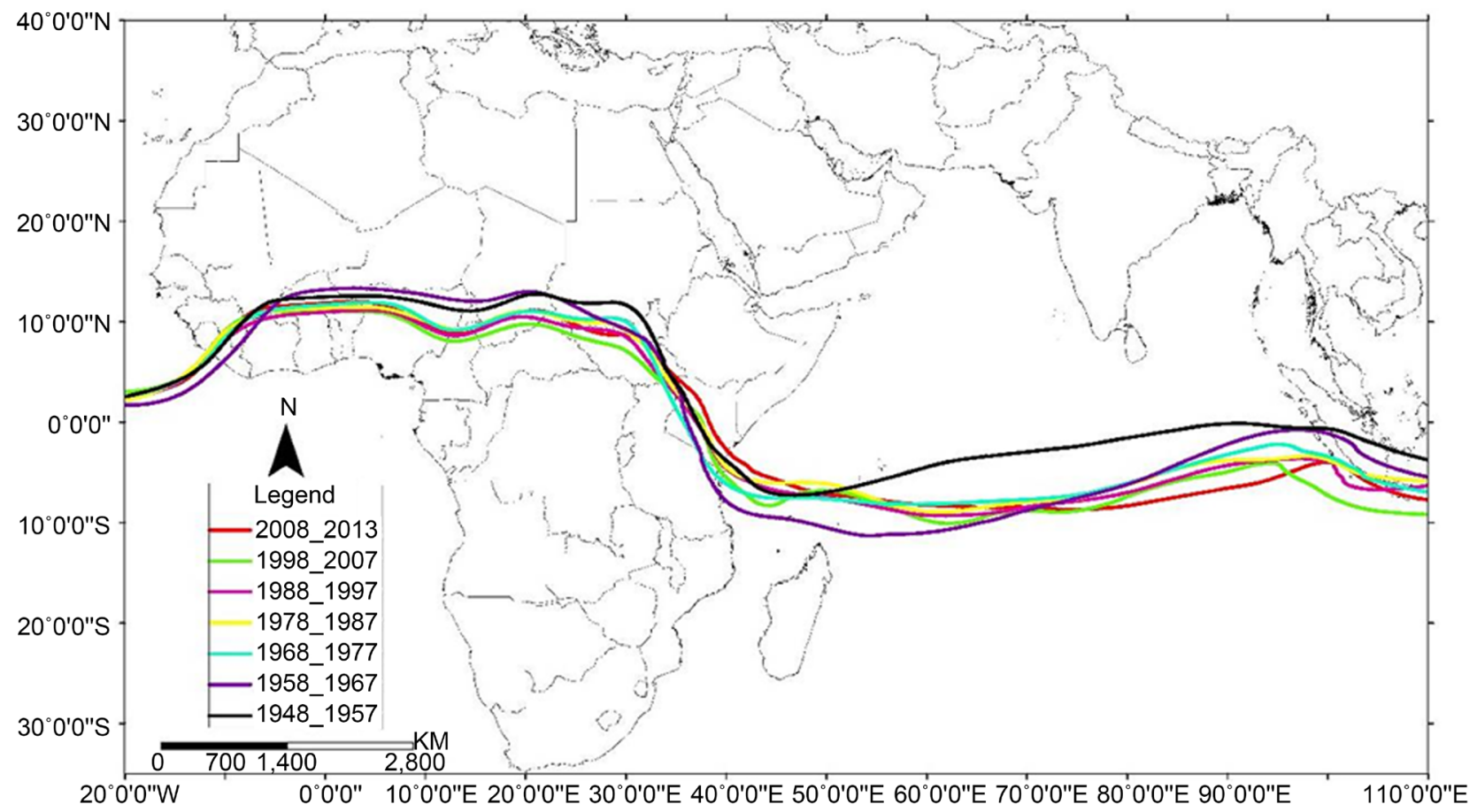

Figure 11. Average position of ITCZ in the periods of ten years. 


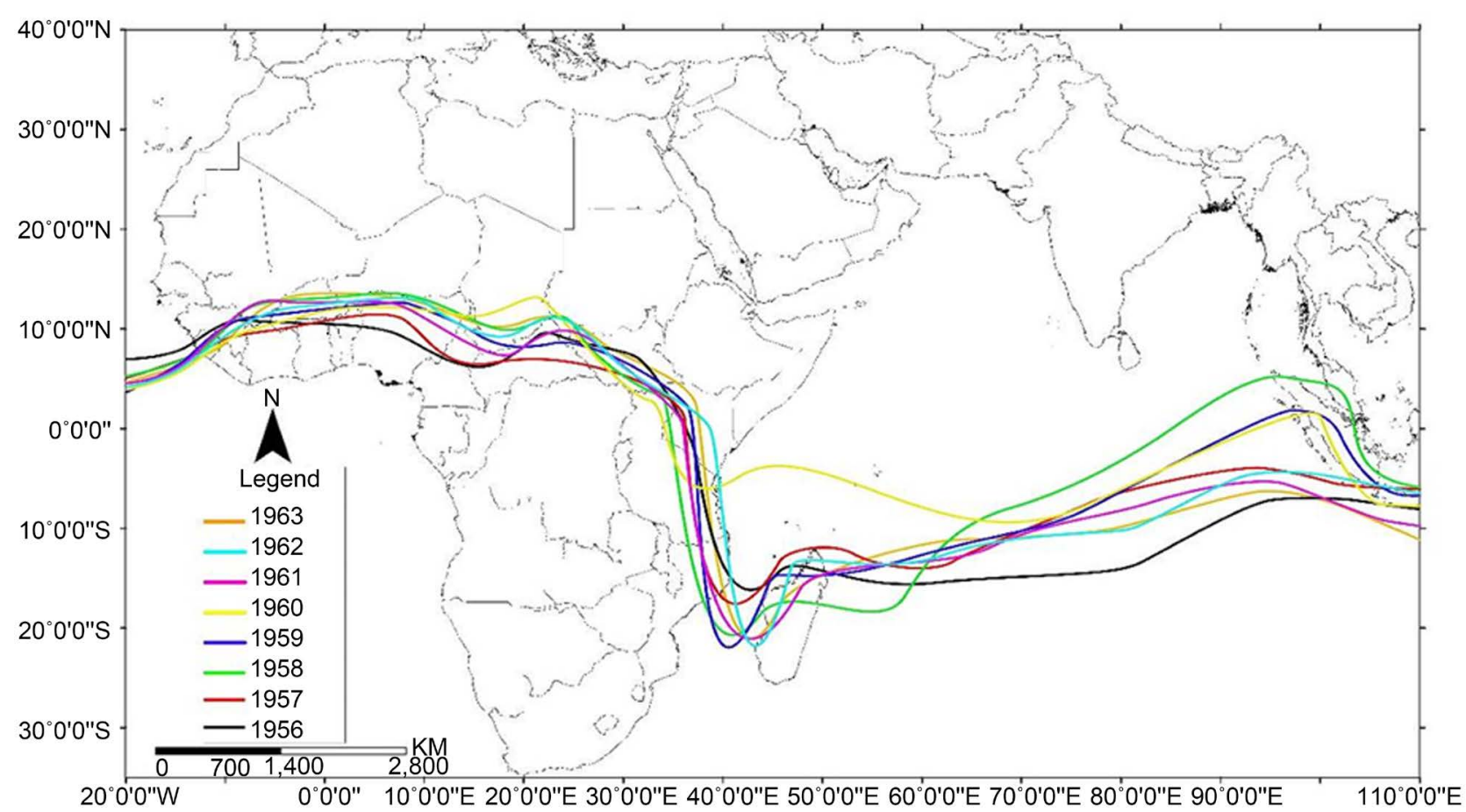

Figure 12. Position and motion path of ITCZ in the statistical period (1956-1963).

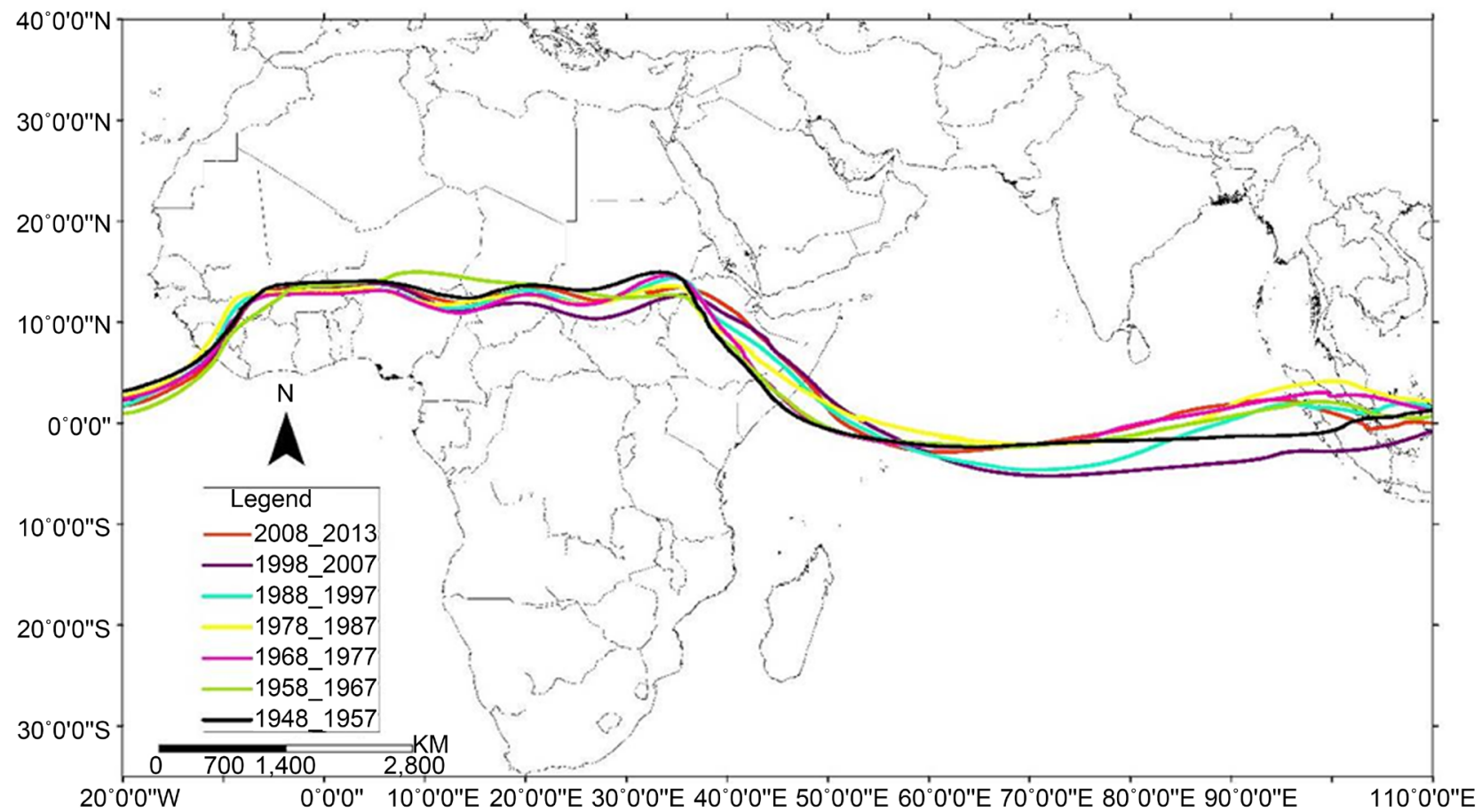

Figure 13. Average position (ITCZ) in periods of ten years.

\subsection{May}

Figure 15 shows the position (ITCZ) in the average periods of ten years. Considering the position (ITCZ) within the range of latitudes $10^{\circ}$ west to $35^{\circ}$ north does not show much changes compared to previous months. In general its position compared to the previous month has 2 to 3 degrees Northern-side dis- 
placement and paths are located in the range of $10^{\circ}$ to $15^{\circ}$ north. But within the range of latitude $40^{\circ}$ to $110^{\circ}$ east the displacement of motion path is significant and remarkable. A sever refraction within the range of latitudes $35^{\circ}$ to $45^{\circ}$ east has been completely vanished and in the whole of this range (ITCZ) has been located on Arabian Peninsula. This displacement within the range of latitudes

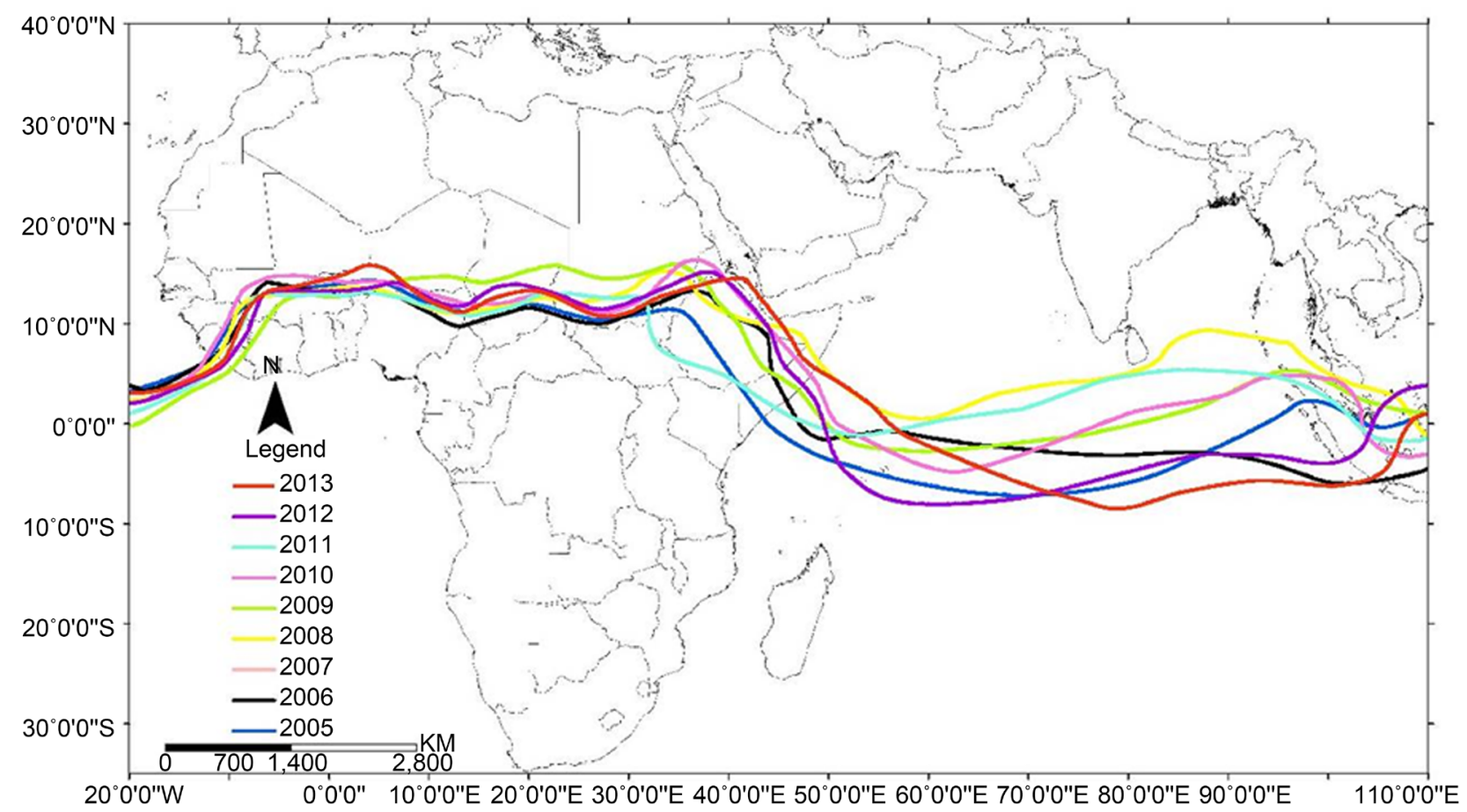

Figure 14. Position and motion path (ITCZ) in the statistical period (2005-2013).

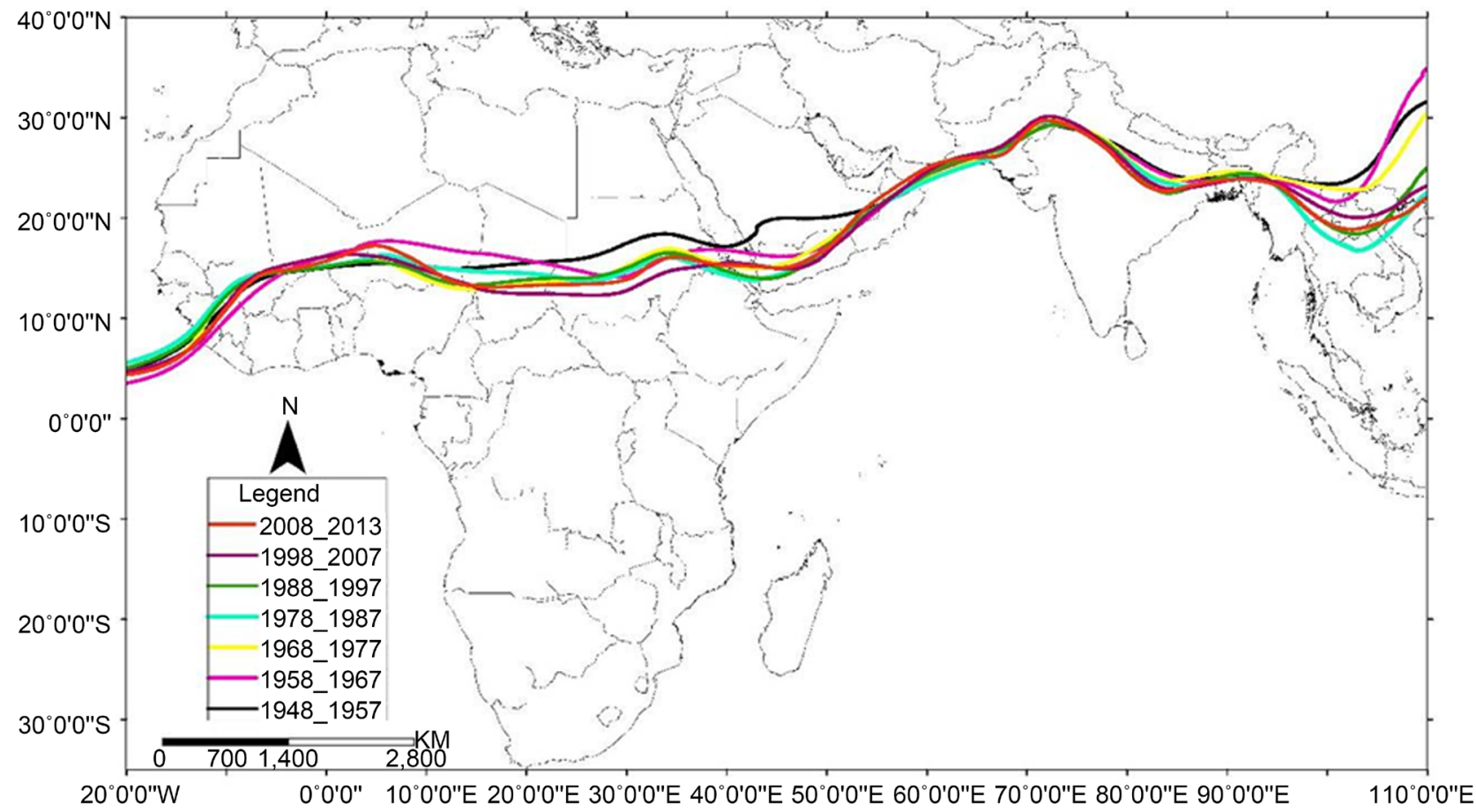

Figure 15. Average position (ITCZ) in periods of ten years. 
$50^{\circ}$ to $80^{\circ}$ east is much more than other positions and ITCZ completely has bent towards high latitudes and has been stretched to the North of India. In some position it has reached to 30 degrees orbit.

In the period of (1988-1995) unlike other periods (ITCZ) in the range of $35^{\circ}$ to $50^{\circ}$ east (South of the Red Sea and Yemen) have had bulge to the South. But in other decades there was a combination of two modes of bulges in the range of Yemen and Saudi Arabia and it was North-sided Figure 16 shows these two different periods.

\subsection{June}

Figure 17 shows the motion pattern (ITCZ) in June in the statistical period of 66 years. The general pattern is very similar to the moon. It does not show many changes in terms of local position.

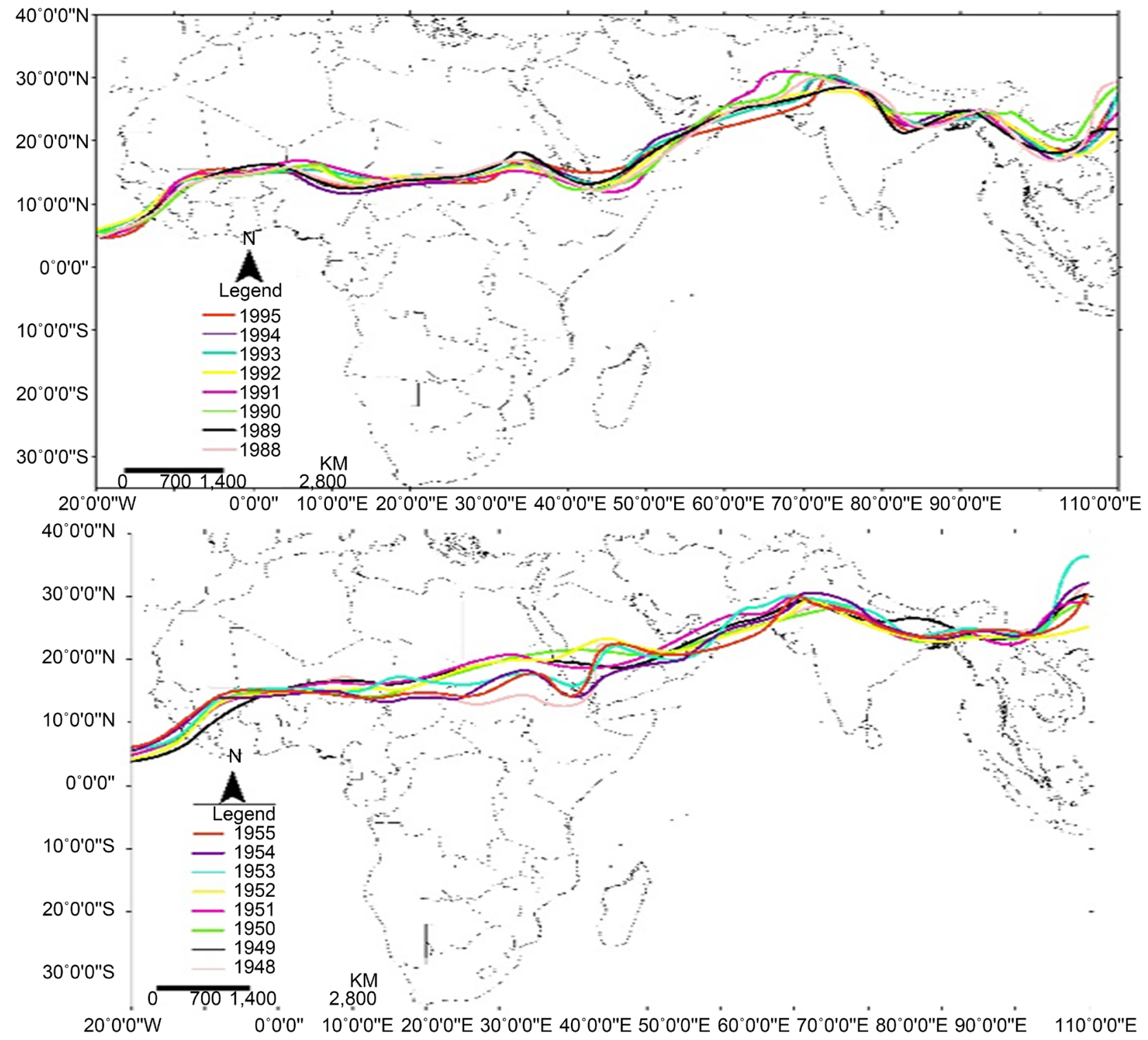

Figure 16. Position and motion path (ITCZ). 


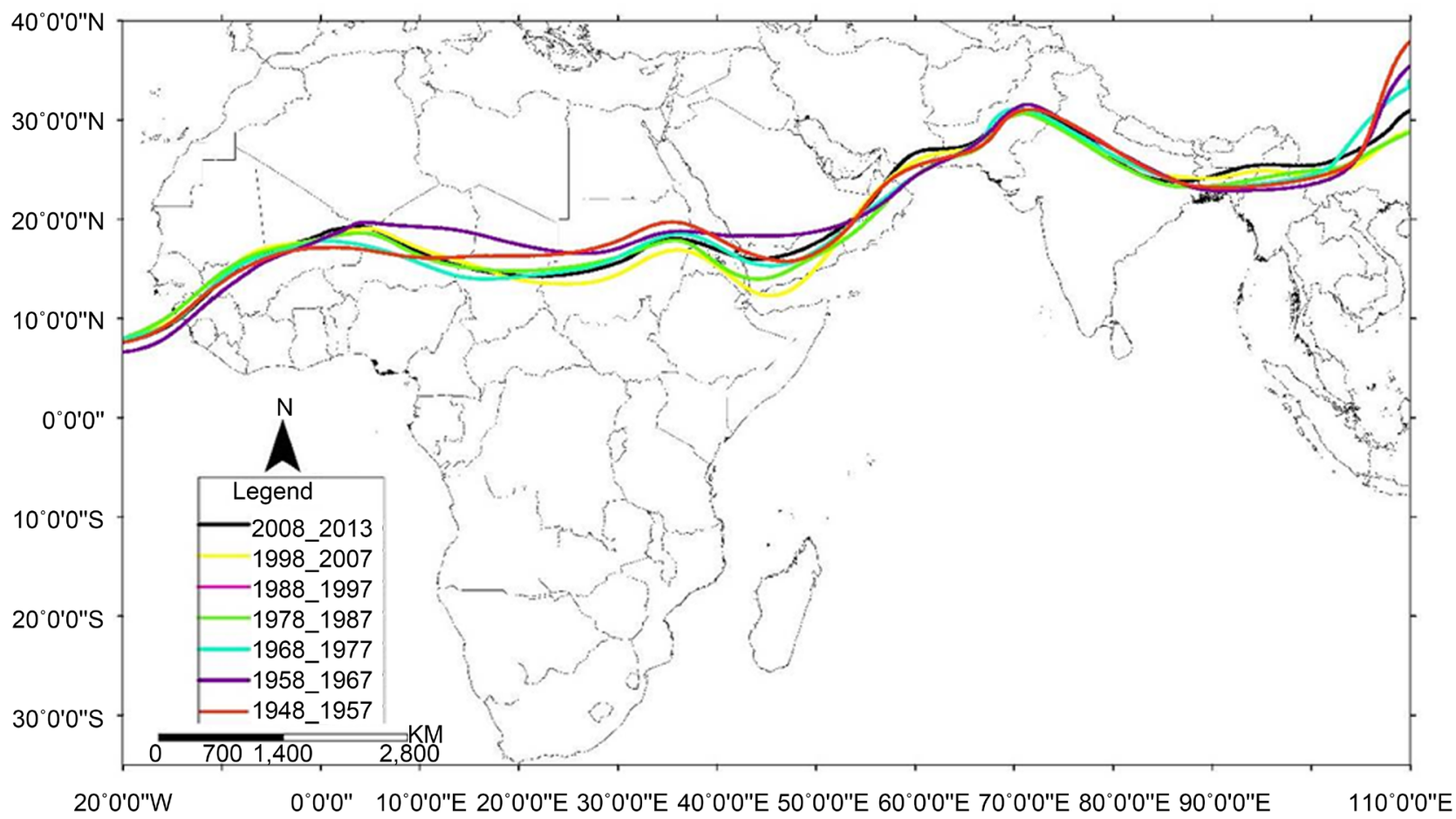

Figure 17. Average position (ITCZ) in the periods of ten years.

There is a minor difference within the Southern range of Red Sea and Yemen. It seems that the motion path of curves have been bent a little towards South. In this month the statistical period of (1988-1995) shows the most regular modes. Also in this month the period (1956-1963) path (ITCZ) unlike other periods within the range of Southern Red Sea and Western Arabia is moving towards North (Figure 18).

\subsection{July}

Also the general pattern in this month is very similar to the pattern in May. Also in this month in the period of (1956-1963) the path of curve (ITCZ) in the Western Arabia and Eastern Red Sea is moving and bending towards South. And in other periods in this range, ITCZ is moving in this range and bending towards South. And in this range curves are completely bending towards South and then are shifting towards North and after passing above Eastern Persian Gulf and Strait of Hormuz, they expand alongside the Southwest-Northeast to the foot of the Himalayas (Figure 19).

In the period of (1948-1955) compared to other periods path of ITCZ on the Red Sea and west of it shows a severe Northern bent. In other periods it has a gradual slope towards North. Figure 20 shows this phenomenon.

\subsection{August}

The general dominant pattern in this month is also the continuation of several previous months before spring and summer. It is also on Africa (ITCZ) within the range of latitudes $10^{\circ}$ to $20^{\circ}$ north. After passing above the Red Sea slopes 

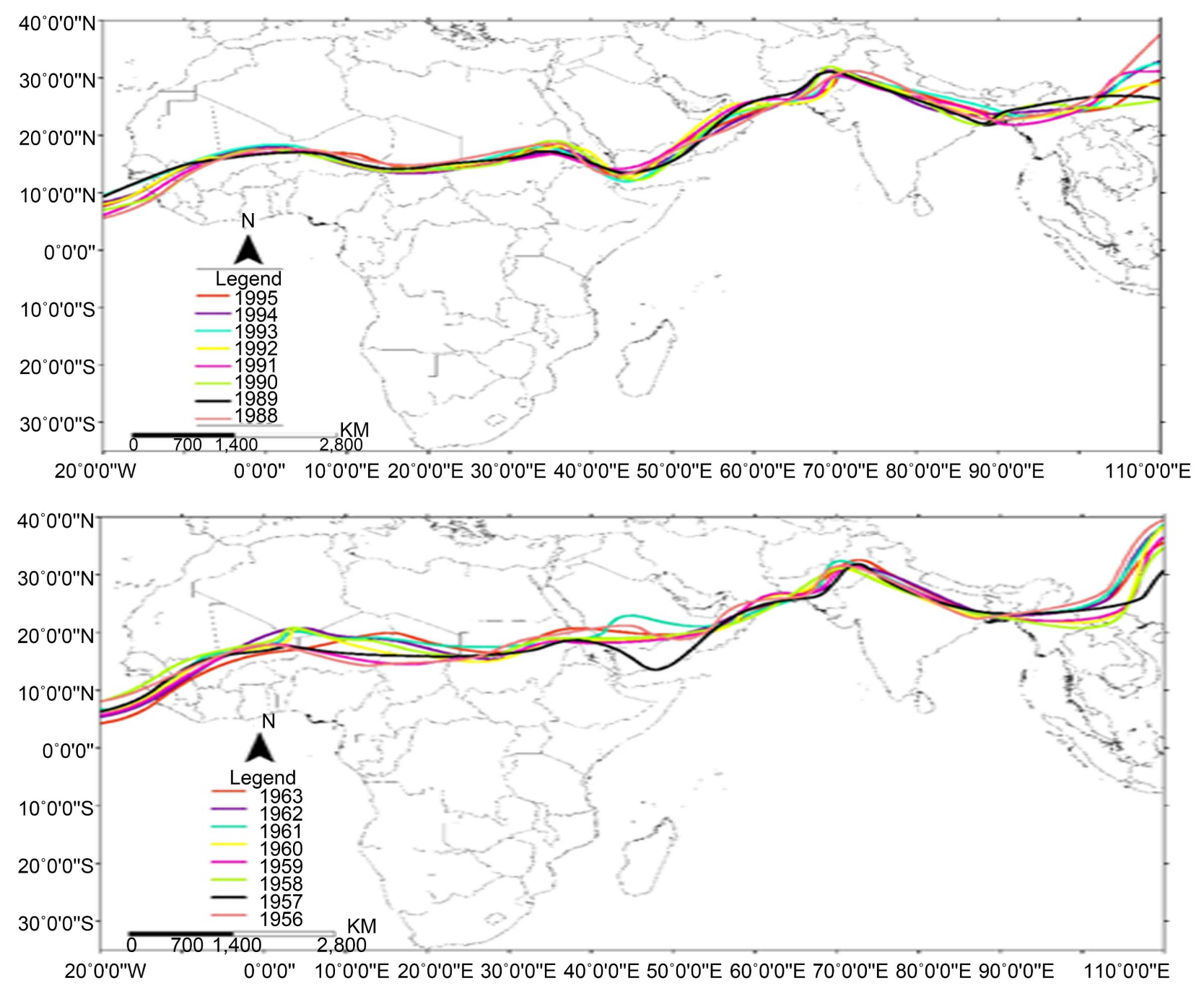

Figure 18. Position and motion path (ITCZ).

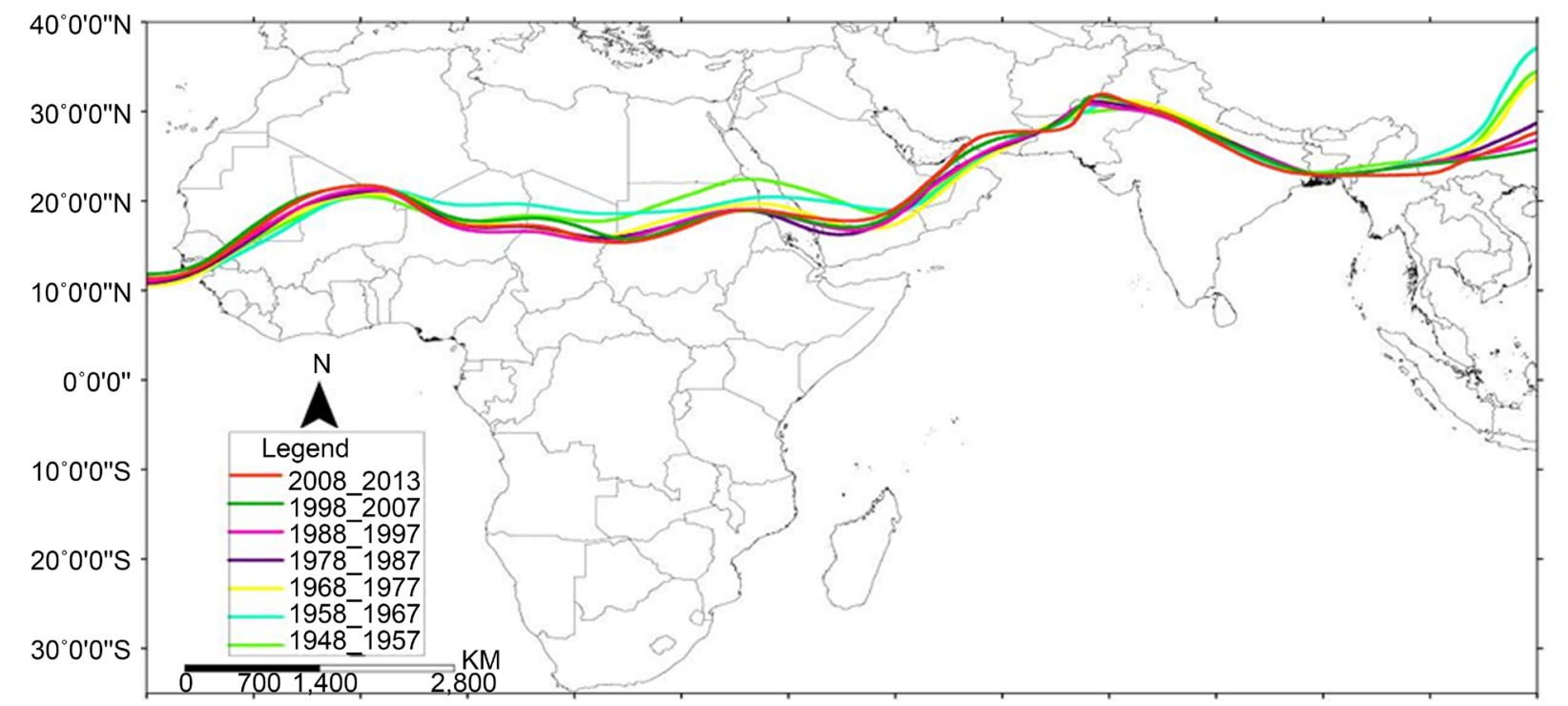

$20^{\circ} 0^{\prime} 0^{\prime \prime} \mathrm{W}$

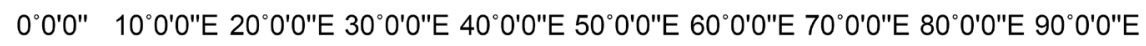

$110^{\circ} 0^{\prime} 0 " \mathrm{E}$

Figure 19. Average position (ITCZ) in periods of ten years. 


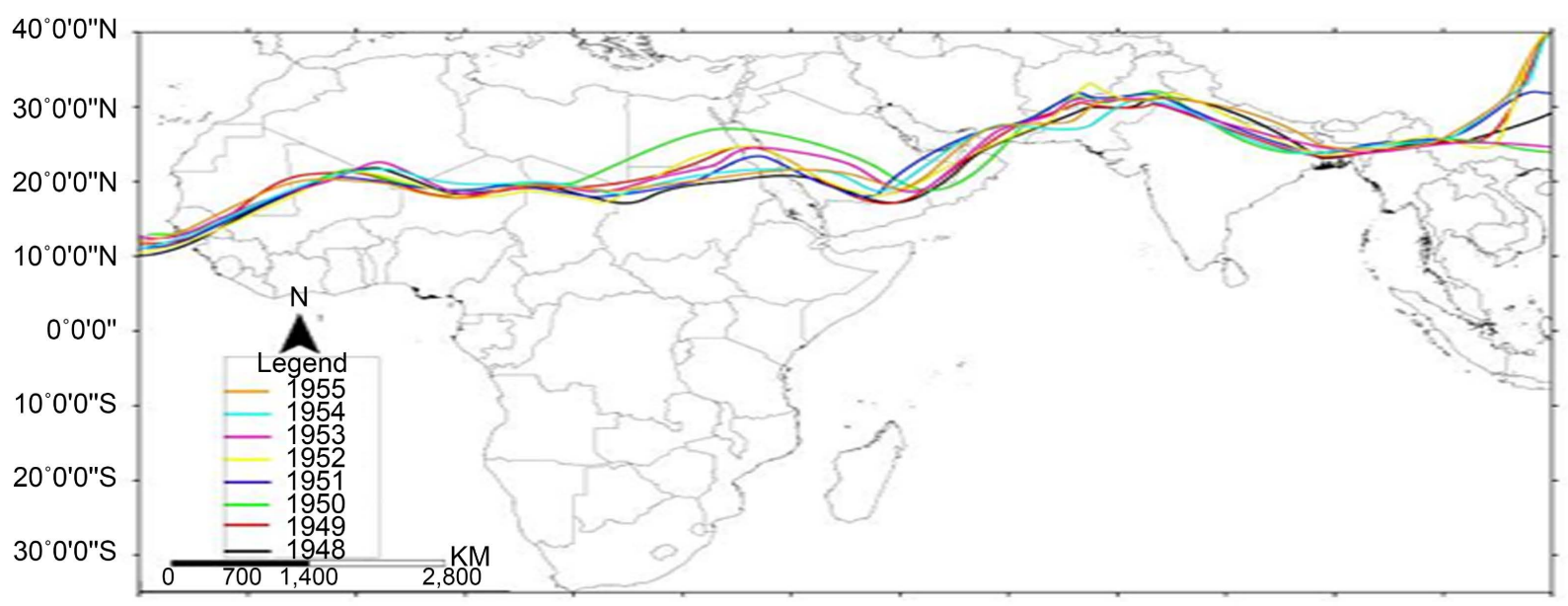

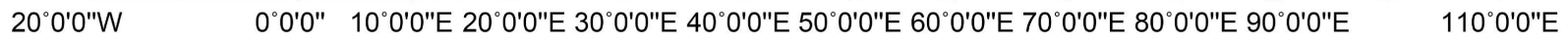

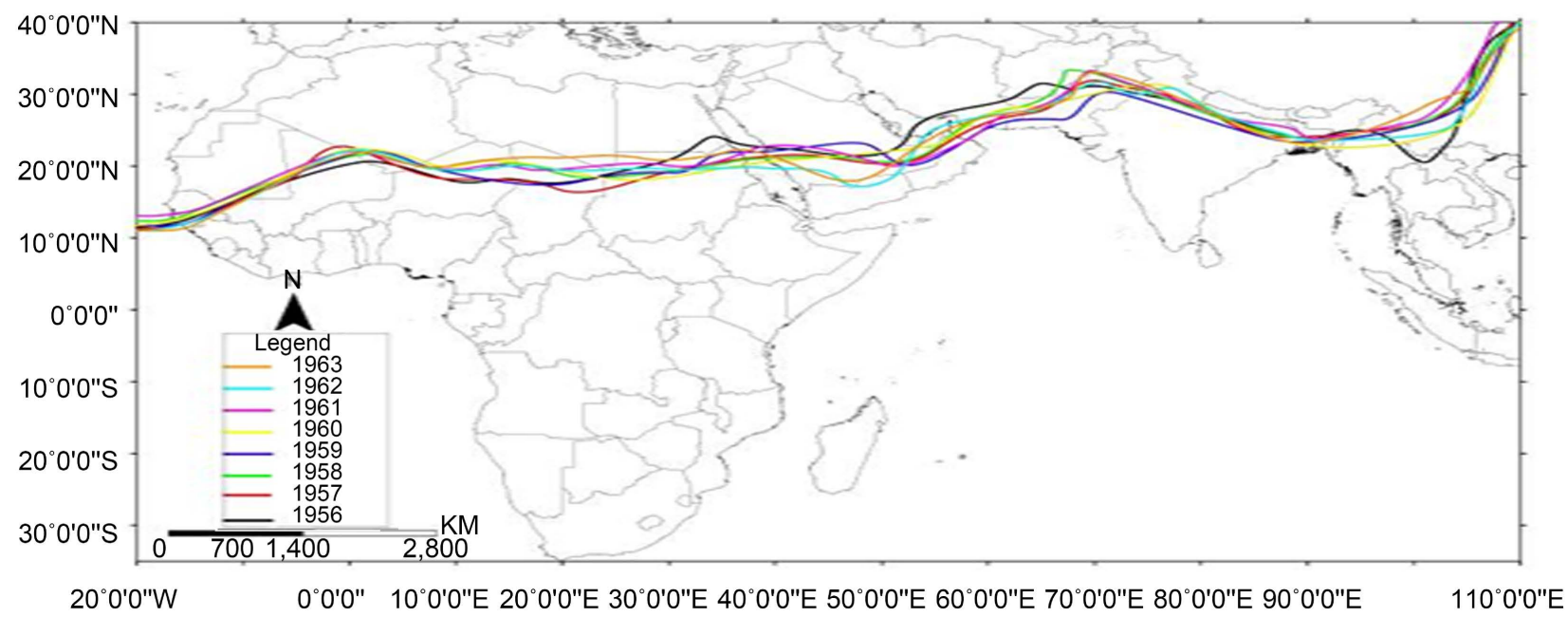

Figure 20. Position and motion path (ITCZ).

bend towards South and after passing the Strait of Hormuz and Southeast of Iran it enters Pakistan and continues to the foot of Himalayas. So that from May onwards the Eastern curve of the Red Sea is gradually moving from South East of the Red Sea towards the East. And it has been shifted on the North of Yemen and East of the Arabian Peninsula. And yet it has gradually been shifted towards North. Figure 21 shows the pattern of August.

\subsection{September}

Figure 22 shows the general dominant pattern in periods of 9 years in September. In this month the same general pattern of other months of summer is dominant. There is a little difference in all positions of ITCZ. So that in all positions it has been moved about 3 to 5 degrees (ITCZ) towards South and it is located in the East of the Red Sea. Figure 23 shows an example of this movement toward the West and South (ITCZ) in decade (1964-1971).

\section{Conclusions}

The Inter Tropical Convergence Zone (ITCZ) has been as the starting location 


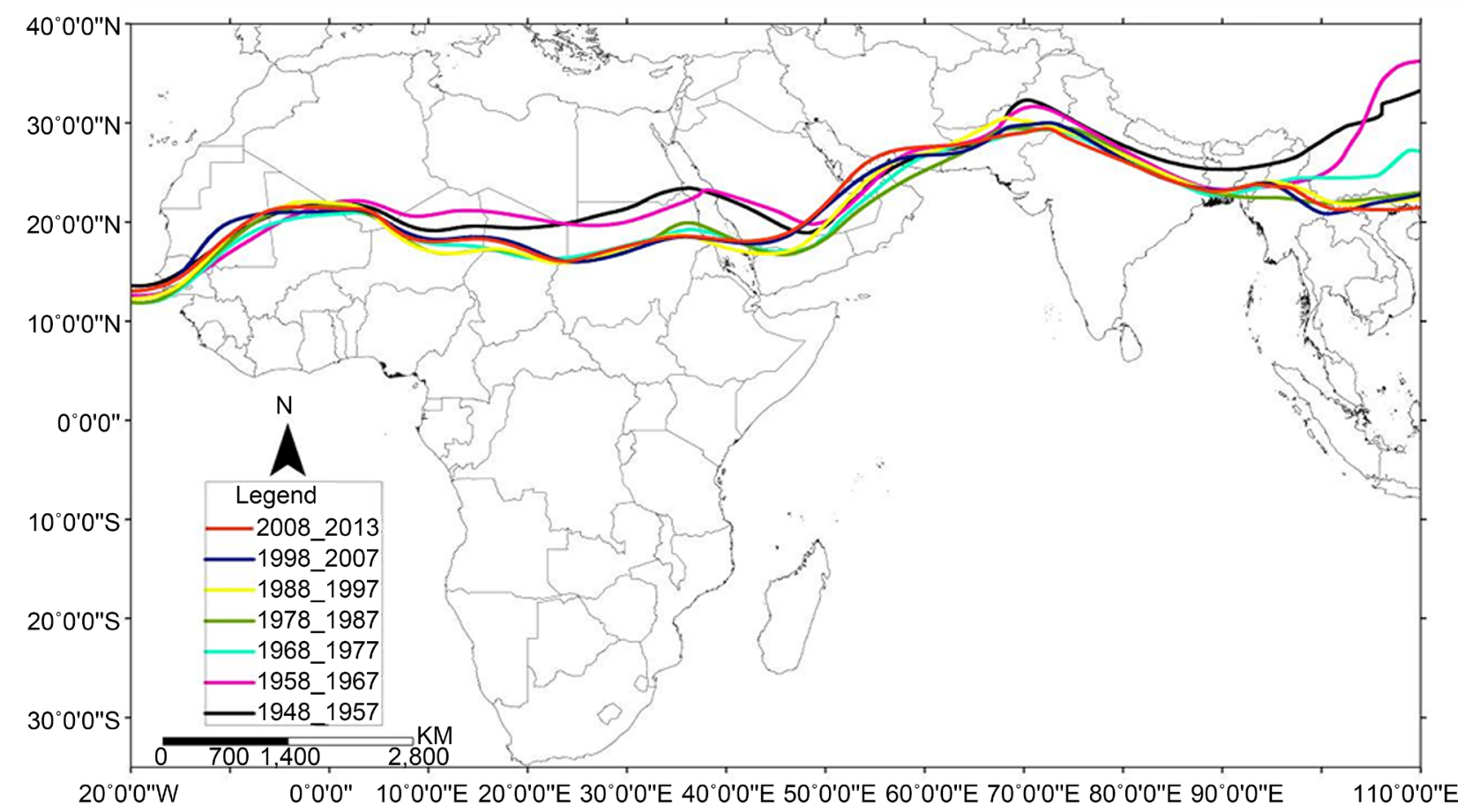

Figure 21. Average position (ITCZ) in the periods of ten years.

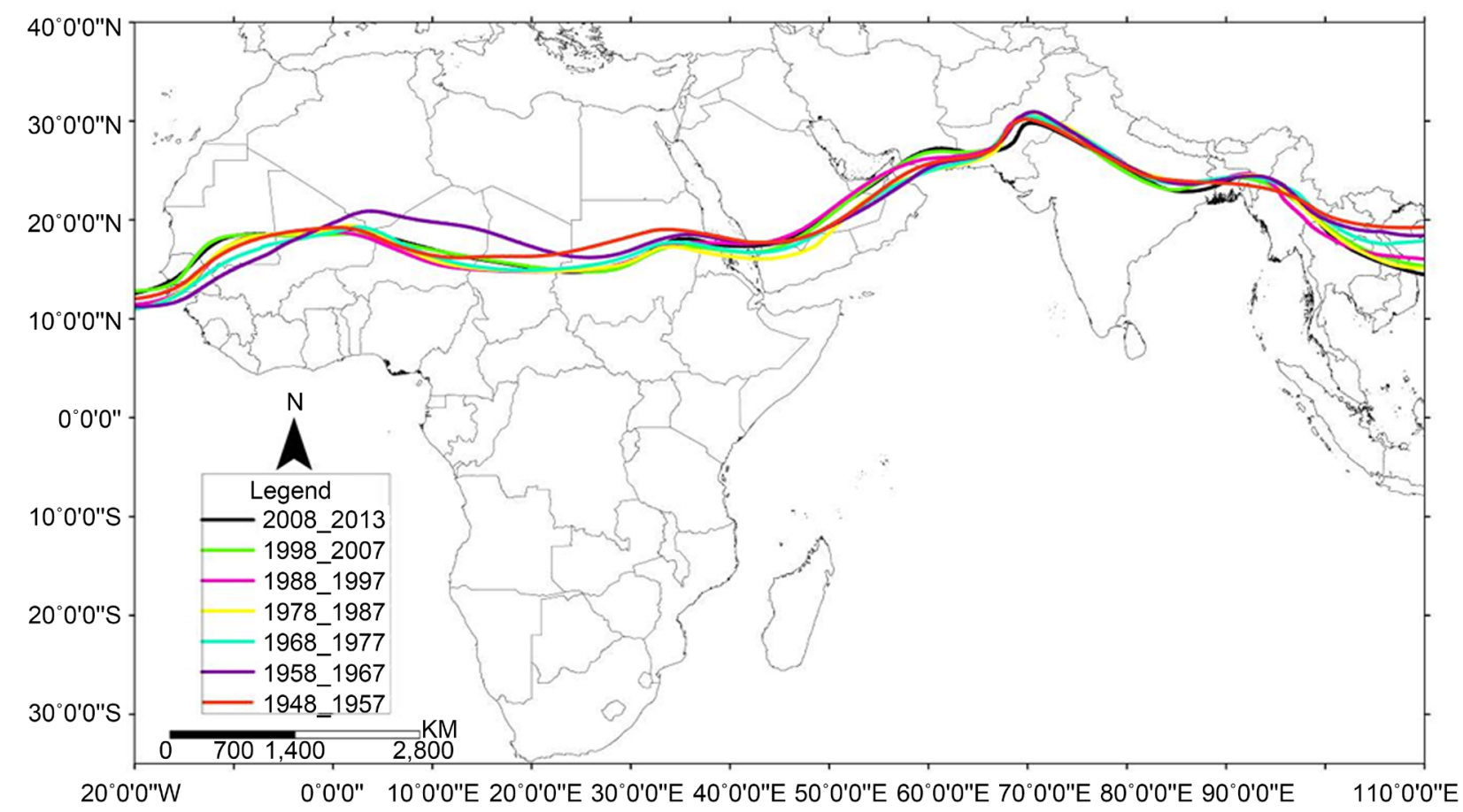

Figure 22. Average position (ITCZ) in the periods of ten years.

or one of the most important and effective systems in the general circulation of atmosphere and it has always attracted the attention of climatologists and atmospheric scientists. The range of latitudes from $20^{\circ}$ west to $110^{\circ}$ east is one of the regions that has allocated a variety of major global climates to itself. The extreme dry climate of Sahara Desert in Africa and the very humid and tropical 


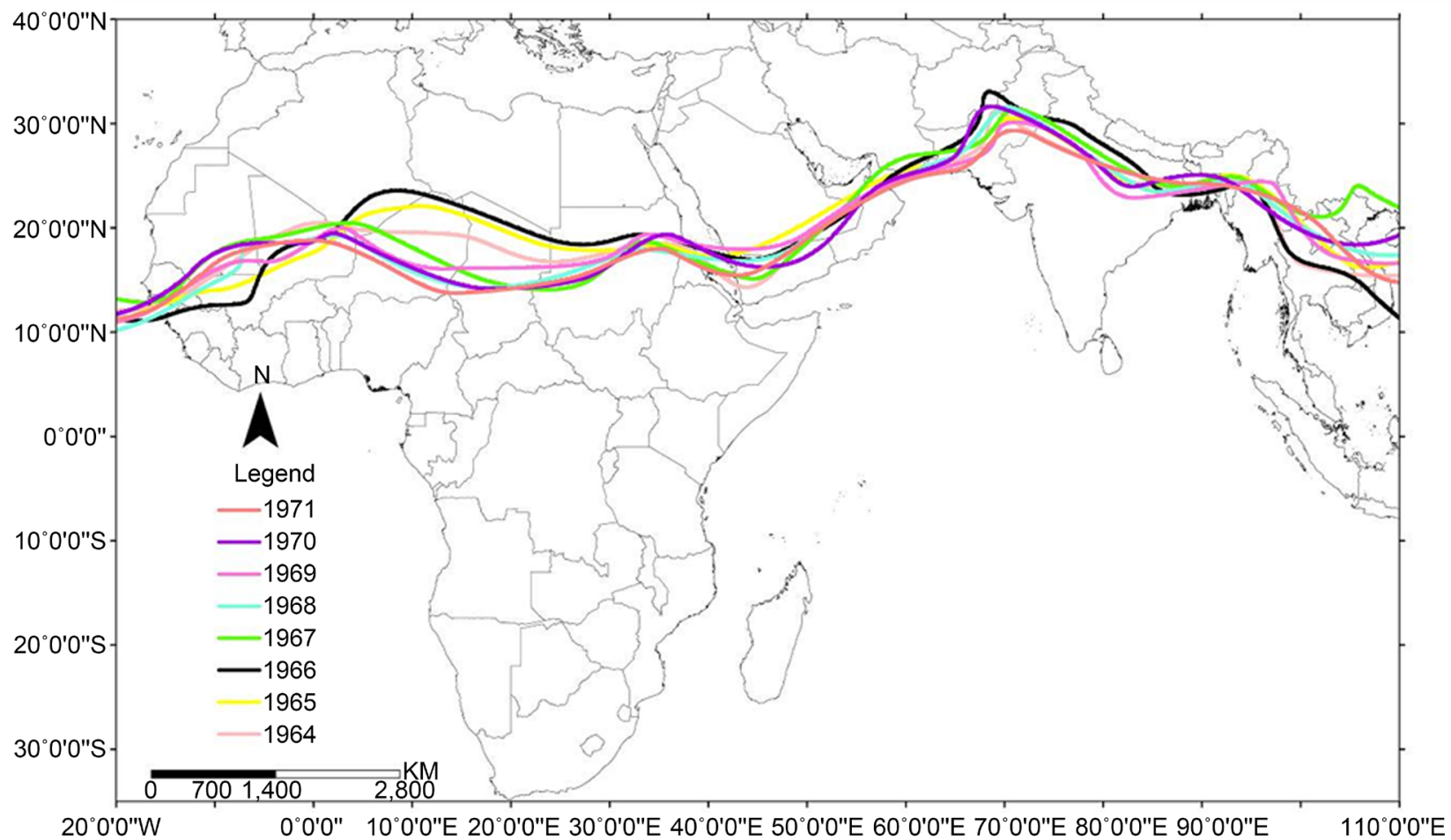

Figure 23. Position and motion path (ITCZ) in the statistical period (1964-1971).

monsoon climate of Indian Subcontinent, are the indicator climates of this region. In this research we have concluded that:

1) The Inter Tropical Convergence Zone within the range of Africa to the Southeast of Asia is not a synchronized solar system. It means that the displacement of ITCZ is not synchronized with the southern and northern displacement of the Sun during the year. Therefore in October in the whole range of $20^{\circ}$ west to $110^{\circ}$ east, ITCZ locates in the range of $10^{\circ}$ north. But in April, ITCZ within the range of Africa $\left(10^{\circ}\right.$ west to $35^{\circ}$ east) is also within the range of orbit $10^{\circ}$ Northern. But near Ethiopia it displaces with a severe refraction towards South and locates near the equator in $5^{\circ}$ south.

2) It seems that ITCZ before Africa (on the Atlantic Ocean) because of moving above the waters of Atlantic Ocean generally has a Southern position and by entering Africa changes with a gradual slope towards higher latitudes. Then in all its way above Sahara Desert of Africa, it has a direct path and very minor fluctuation.

3) The position of ITCZ is located on the Sahara desert of Africa above the equator during the whole year. So that its position is located within the range of orbit $10^{\circ}$ north in cold months of the year (autumn and winter of Northern hemisphere) and is located within the range of orbit $20^{\circ}$ north in warm months of the year (spring and summer).

4) After latitudes of $35^{\circ}$ to $45^{\circ}$ east, the displacement is very severe and as a result of seasonal changes sometimes they have a displacement up to 50 degrees latitude.

5) May and November are the months of changes in the pattern of structure 
(ITCZ) and the displacement is severe in the position of ITCZ within the range of $35^{\circ}$ to $110^{\circ}$ east (The Middle East and Southeast Asia). In fact these two months are the transitional months in the pattern of this region (ITCZ).

5) In the winter pattern (ITCZ) almost from November to April which includes 6 months of the year (ITCZ) and it complies with this pattern. After the latitude of $10^{\circ}$ west, path of ITCZ has an orbital mode on Africa and is located within the range of orbit $10^{\circ}$ north. Then within the range of latitudes from $30^{\circ}$ to $35^{\circ}$ east (Ethiopia) with a sudden change of path, it enters the Southern hemisphere and it moves towards South about 20 degrees latitude. Then on the Indian Ocean it moves a little towards North and with minor fluctuations it extends to $110^{\circ}$ east.

[The reason of this slope and severe refraction in the motion path of ITCZ on Ethiopia, is the Southern-side displacement of Arabia high pressure cell, in the cold period of the year. So that January has the most southern-side motion of Arabia high pressure cell, and also has the most slope (see Figure 5 and Figure 6). On the other hand, by reinforcing the Siberian high pressure and its Southern-side motion, the southern tab of this high pressure, after passing the East of Iran and Afghanistan will influence on the Gulf of Oman, Arabian Sea and East of Arabian Peninsula. And the cold air advection will help the Southern-side motion of ITCZ.]

6) Summer pattern of ITCZ in this geographical range is that ITCZ enters Africa above waters of the Atlantic Ocean, within the range of $10^{\circ}$ north latitude with a gradual slope and will be stretched within the range of $20^{\circ}$ to $22^{\circ}$ north latitude to $35^{\circ}$ east (Sudan). Within the range of Sudan, curves will bend a little towards North. But after passing the Red Sea, they will be stretched towards South as a tangible wave. By approaching the hot months of summer, the southern bend moves slightly towards East and reaches the East of Saudi Arabia. Then, ITCZ will shift towards North with a significant slope. And after passing Oman, Strait of Hormuz and southeast of Iran, it stretches along the foot of Himalayas. In this zone, ITCZ has the highest Northern motion of its own. Therefore sometimes, ITCZ reaches $30^{\circ}$ north and perhaps it is the highest northern shift in the Northern hemisphere. Then it will redirect a little towards South. [This remarkable displacement of ITCZ in the hot period of the year towards the northern latitudes, is due to the remarkable displacement of high pressure tropical cell of India in higher balances towards North. As well as the remarkable withdrawal of Siberian, high pressure is towards the higher latitudes. This significant displacement of (ITCZ) in this zone will be the area for the penetration of the monsoon winds from southern hemisphere and development of monsoon systems. Wave on the Eastern Red Sea is due to the southern-side expansion of Saudi Arabia high pressure tab. And in this period of the year, its central core is located on the south of Iraq and northwest of Saudi Arabia.]

Also the special results of this study could be mentioned as follow:

- Unlike the popular belief, ITCZ belt does not follow displacement of the Sun in the cold period of the year. And during the whole cold period of the year, 
(October to April) is located on African Sahara in North of the Equator.

- In some years ITCZ has been out of normal state and does not follow the general form of that month. And the reason for this anomaly should be studies in another research.

- In the whole cold period of the year, a severe refraction can be seen in the motion path of ITCZ bar on the northeast of Africa and this issue was not considered in the conducted research.

- Seasonal displacement of ITCZ especially, from spring to summer is sudden and severe and this result is synchronized with the results of work [16] [17] about the sudden displacements of ITCZ on Indian Ocean and Egypt.

- In the hot period of the year a sever refraction has been took place on the motion path of ITCZ bar on the east of Arabia. And ITCZ belt rises to the south of Himalaya with a severe northern-side movement [18]. They have mentioned about the ITCZ refractions, in the center and east of Pacific Ocean.

\section{References}

[1] Schulman, L.L. (1973) On the Summer Hemisphere Hadley Cell. Quarterly Journal of Royal Meteorological Society, 99, 197-201.

https://doi.org/10.1002/qj.49709941916

[2] Folland, C.K., Colman, A.W., Rowell, D.P. and Davey, M.K. (2001) Predictability of Northeast Brazil Rainfall and Real-Time Forecast Skill, 1987-1998. Journal of Climate, 14, 1937-1958. https://doi.org/10.1175/1520-0442(2001)014<1937:PONBRA>2.0.CO;2

[3] Waliser, D.E. and Gautier, C. (1993) A Satellite-Derived Climatology of the ITCZ. Journal of Climate, 6, 2162-2174. https://doi.org/10.1175/1520-0442(1993)006<2162:ASDCOT>2.0.CO;2

[4] Gu, G. and Zhang, C. (2002) Cloud Components of the Intertropical Convergence Zone. Journal of Geophysical Research, 107, 4565. https://doi.org/10.1029/2002JD002089

[5] Arbuszewski, J.A., Cléroux, C., Bradtmiller, L. and Mix, A. (2013) Meridional Shifts of the Atlantic Intertropical Convergence Zone since the Last Glacial Maximum. Nature Geoscience, 6, 959-962. https://doi.org/10.1038/ngeo1961

[6] Sachs, J., Stege, M. and Keju, T. (2009) Recent Movements of the ITCZ in the Tropical Pacific and Ramifications for the Marshall Islands. IOP Conference Series. Earth and Environmental Science, 6, Article ID: 072010.

https://doi.org/10.1088/1755-1307/6/7/072010

[7] Engelstaedter, S., Tegen, I. and Washington, R. (2006) North African Dust Emissions and Transport. Earth-Science Reviews, 79, 73-100. https://doi.org/10.1016/j.earscirev.2006.06.004

[8] Engelstaedter, S. and Washington, R. (2007) Atmospheric Controls on the Annual Cycle of North African Dust. Journal of Geophysical Research, 112, D03103. https://doi.org/10.1029/2006jd007195

[9] Klose, M., Shao, Y., Karremann, M.K. and Fink, A.H. (2010) Sahel Dust Zone and Synoptic Background. Geophysical Research Letters, 37, L09802. https://doi.org/10.1029/2010gl042816

[10] Tesche, M., Gross, S., Ansmann, A., Muller, D., Althausen, D. and Freudenthaler, V. 
(2011) Profiling of Saharan Dust and Biomass Burning Smoke with Multiwavelength Polarization Raman Lidar at Cape Verde. Tellus, 63B, 649-676. https://doi.org/10.1111/j.1600-0889.2011.00548.x

[11] $\mathrm{Pu}, \mathrm{B}$. and Cook, K.H. (2010) Dynamics of the Low-Level Westerly Jet over West Africa. Bulletin of the American Meteorological Society, 40, 6263-6276.

[12] Jickells, T., Dorling, S., Deuser, W., Church, T., Arimoto, R. and Prospero, J. (1998) Air-Borne Dust Fluxes to a Deep Water Sediment Trap in the Sargasso Sea. Global Biogeochemical Cycles, 12, 311-320. https://doi.org/10.1029/97GB03368

[13] .Goudie, A.S. and Middleton, N.J. (2001) Saharan Dust Storms: Nature and Consequences. Earth-Science Reviews, 56, 179-204. https://doi.org/10.1016/S0012-8252(01)00067-8

[14] Rajendran, K., Kitoh, A. and Srinivasan, J. (2013) Effect of SST Variation on ITCZ in APE Simulations. Journal of the Meteorological Society of Japan, 91, 195-215. https://doi.org/10.2151/jmsj.2013-A06

[15] Lashkari, H. and Mohamadi, Z. (2015) The Role of Saudi Arabian Sub-Tropical High Pressure on the Rainfall Systems on South and Southwest Iran. Physical Geography Research Quarterly, 47, 10-11. http://en.journals.sid.ir/ViewPaper.aspx?ID=461521

[16] Hu, Y., Li, D. and Liu, J. (2007) Abrupt Seasonal Variation of the ITCZ and the Hadley Circulation. Geophysical Research Letters, 34, L18814. https://doi.org/10.1029/2007gl030950

[17] Hafez, Y. and Almazroui, M. (2016) Study of the Relationship between African ITCZ Variability and an Extreme Heat Wave on Egypt in Summer 2015. Arabian Journal of Geosciences, 9, 476. https://doi.org/10.1007/s12517-016-2497-4

[18] Wang, B. and Ho, L. (2002) Rainy Season of the Asian-Pacific Summer Monsoon. Journal of Climate, 15, 386-398.

https://doi.org/10.1175/1520-0442(2002)015<0386:RSOTAP $>2.0 . C O ; 2$

\section{Scientific Research Publishing}

Submit or recommend next manuscript to SCIRP and we will provide best service for you:

Accepting pre-submission inquiries through Email, Facebook, LinkedIn, Twitter, etc. A wide selection of journals (inclusive of 9 subjects, more than 200 journals)

Providing 24-hour high-quality service

User-friendly online submission system

Fair and swift peer-review system

Efficient typesetting and proofreading procedure

Display of the result of downloads and visits, as well as the number of cited articles

Maximum dissemination of your research work

Submit your manuscript at: http://papersubmission.scirp.org/

Or contact oje@scirp.org 